\title{
Development and Demonstration of Mobile, Small Footprint Exploration and Development Well System for Arctic Unconventional Gas Resources (ARCGAS)
}

Final Report: Field Demonstration Results

An R\&D Demonstration Sponsored By:

U.S. Department of Energy, National Petroleum Technology Office

Contract No. DE-FC26-01BC15151

Performed By:

Advanced Resources International, Inc.

With Cooperative Research Partners:

Nana Development Corporation

Teck Cominco

November 2002 


\section{Disclaimer}

This report was prepared as an account of work sponsored by an agency of the United States Government. Neither the United States Government nor any agency thereof, nor any of their employees, makes any warranty, express or implied, or assumes any legal liability or responsibility for the accuracy, completeness, or usefulness of any information, apparatus, product, or process disclosed, or represents that its use would not infringe privately owned rights. Reference herein to any specific commercial product, process, or service by trade name, trademark, manufacturer, or otherwise does not necessarily constitute or imply its endorsement, recommendation, or favoring by the United States Government or any agency thereof. The views and opinions of authors expressed herein do not necessarily state or reflect those of the United States Government or any agency thereof." 


\section{Disclaimer}

The material in this Report is intended for general information only. Any use of this material in relation to any specific application should be based on independent examination and verification of its unrestricted applicability for such use and on a determination of suitability for the application by professionally qualified personnel. No license under any Advanced Resources International, Inc. patents or other proprietary interest is implied by the publication of this Report. Those making use of or relying upon the material assume all risks and liability arising from such use or reliance. 


\section{Tables of Contents}

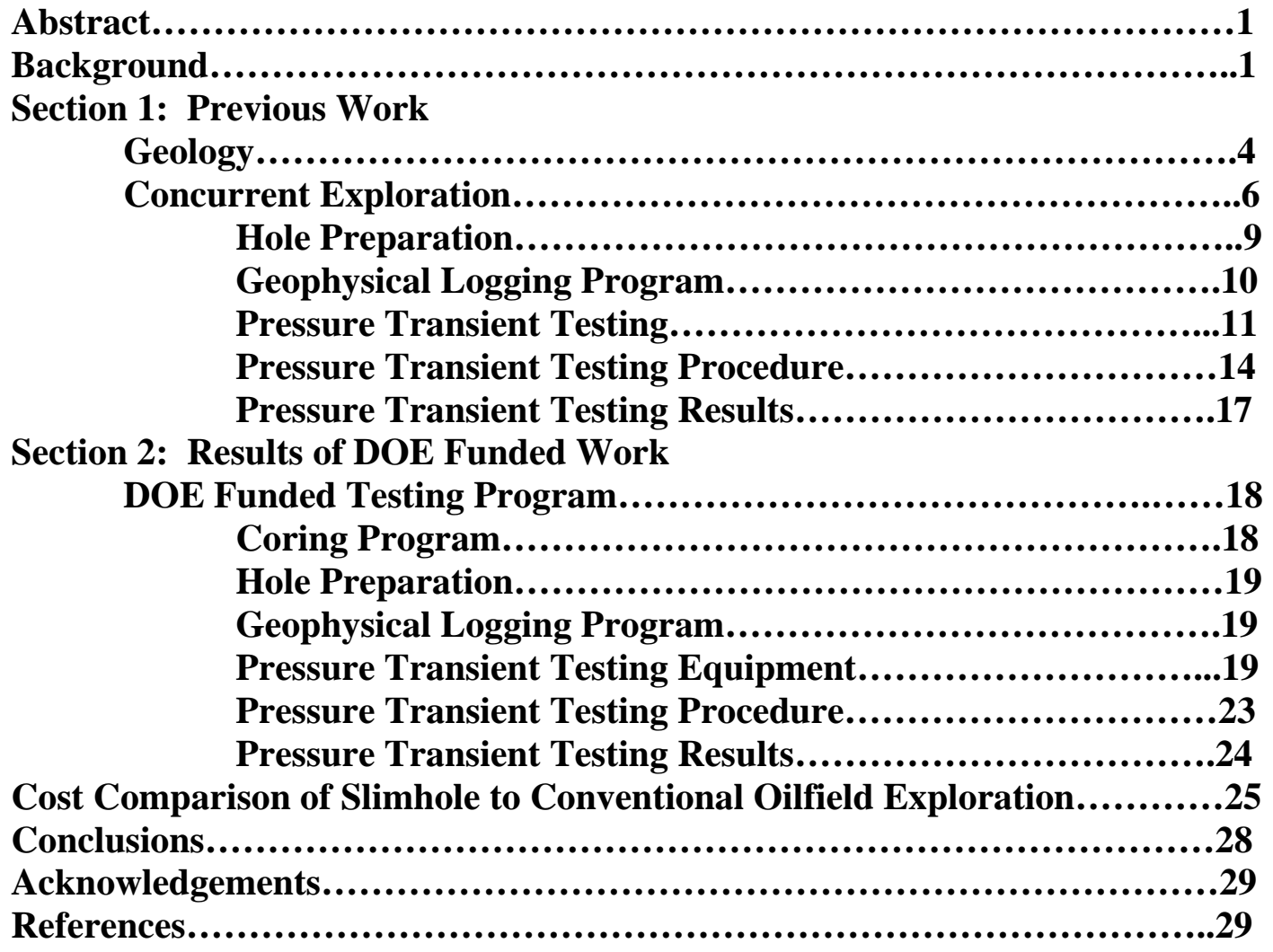

Appendix A - Multiple Zone Pressure Transient Testing Program Utilized at Red Dog Mine...............................................30 


\section{Table of Figures}

Figure 1 - Location of the Red Dog Mine......................................................................... 2

Figure 2 - Zinc deposits in the vicinity of the Red Dog Mine ................................... 3

Figure 3 - Relative locations of the Wulik and North Basins to the Red Dog Mine... 4

Figure 4 - Generalized stratigraphic column.............................................................. 5

Figure 5 - Relative positions and thicknesses of the Ikalukrok and Kivalina shales 5

Figure $6-1998$ and 1999 gas content analysis results............................................. 7

Figure 7 - Comparison of representative shale plays to the Kuna Formation ........... 7

Figure 8 - Fully saturated Kuna Formation adsorption isotherm................................ 8

Figure 9 - Comparison of Ikalukrok shale's adsorption isotherm to other shale

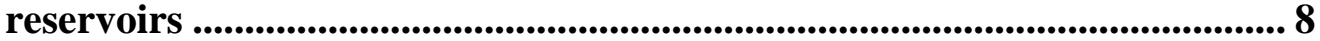

Figure 10 - 2000 Gas content analysis results .................................................9

Figure 11 - Freeze depression of propylene and ethylene glycol as a function of mixing weight ...................................................................................... 10

Figure 12 - Diameters and lengths of Reeves wireline logging tools......................... 11

Figure 13 - Geophysical well log response ............................................................ 13

Figure 14 - Acoustic borehole televeiwer response, drillhole 945 ............................. 14

Figure 15 - Tigre Tierra Model 23 B sliding end packer (after Tigre Tierra).......... 16

Figure 16 - Surface injection rate and pressure monitoring equipment .................... 17

Figure 17 - Surface inflation testing .................................................................................. 17

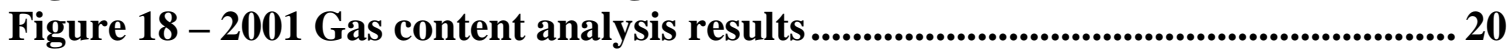

Figure 19 - Straddle packer system configuration with equipment insets................ 22

Figure 20 - Surface inflation equipment in use ........................................................ 23

\section{List of Tables}

Table 1 - 2000 Red Dog Mine Gas Exploration Packer Test Results ......................... 18

Table 2 - 2001 Red Dog Mine Gas Exploration Packer Test Results ......................... 25

Table 3 - Ranked pressure transient tests with core and log characteristics............ 26

Table 4 - Cost comparison of slimhole and conventional oilfield 4-well exploration programs 


\section{Abstract}

Traditionally, oil and gas field technology development in Alaska has focused on the high-cost, high-productivity oil and gas fields of the North Slope and Cook Inlet, with little or no attention given to Alaska's numerous shallow, unconventional gas reservoirs (carbonaceous shales, coalbeds, tight gas sands). This is because the high costs associated with utilizing the existing conventional oil and gas infrastructure, combined with the typical remoteness and environmental sensitivity of many of Alaska's unconventional gas plays, renders the cost of exploring for and producing unconventional gas resources prohibitive.

To address these operational challenges and promote the development of Alaska's large unconventional gas resource base, new low-cost methods of obtaining critical reservoir parameters prior to drilling and completing more costly production wells are required. Encouragingly, low-cost coring, logging, and in-situ testing technologies have already been developed by the hard rock mining industry in Alaska and worldwide, where an extensive service industry employs highly portable diamonddrilling rigs.

From 1998 to 2000, Teck Cominco Alaska employed some of these technologies at their Red Dog Mine site in an effort to quantify a large unconventional gas resource in the vicinity of the mine. However, some of the methods employed were not fully developed and required additional refinement in order to be used in a cost effective manner for rural arctic exploration. In an effort to offset the high cost of developing a new, low-cost exploration methods, the US Department of Energy, National Petroleum Technology Office (DOE-NPTO), partnered with the Nana Regional Corporation and Teck Cominco on a technology development program beginning in 2001.

Under this DOE-NPTO project, a team comprised of the NANA Regional Corporation (NANA), Teck Cominco Alaska and Advanced Resources International, Inc. (ARI) have been able to adapt drilling technology developed for the mineral industry for use in the exploration of unconventional gas in rural Alaska. These techniques have included the use of diamond drilling rigs that core small diameter $(<$ 3.0-inch) holes coupled with wireline geophysical logging tools and pressure transient testing units capable of testing in these slimholes.

\section{Background}

First discovered in 1953 by pilots flying over a mineral stained area in Northwest Alaska, the Red Dog Mine is located in the DeLong Mountains of the western Brooks Range, 90 miles north of Kotzebue (Figure 1). In 1989, Cominco Alaska (now Teck Cominco Alaska, Inc.) began initial zinc and lead production on lands leased from the NANA Corporation. Today, Red Dog is the world's largest zinc mine, milling 
$3,357,000$ tons $(3,045,100$ tonnes) of ore in 2000 and producing 1,058,000 tons (959,800 tonnes) of zinc concentrate ${ }^{1}$.

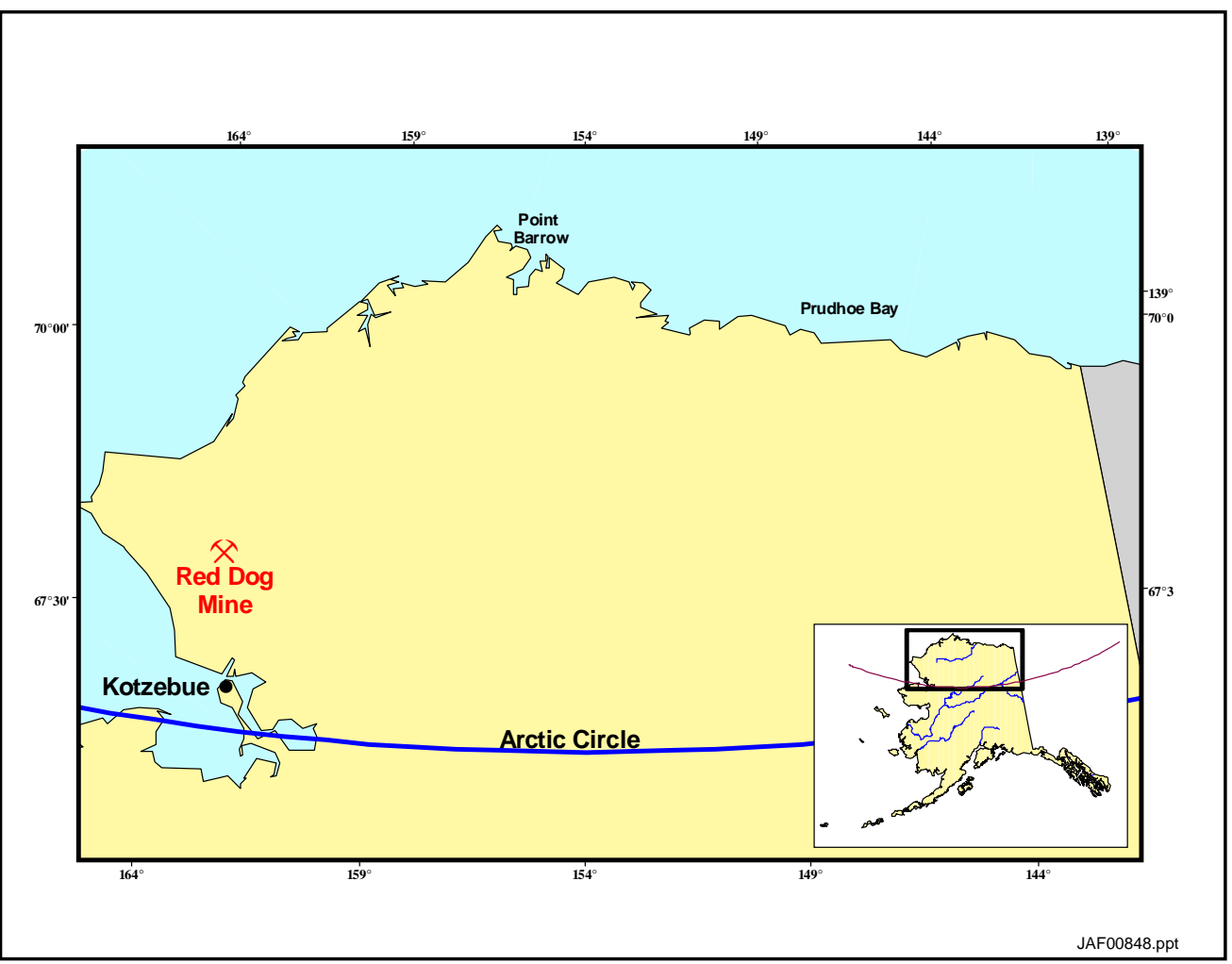

Figure 1 - Location of the Red Dog Mine

During 2001, an extensive exploration program for additional zinc deposits in the vicinity of the mine site on a year round basis. The exploration program at Red Dog is implemented in two strategic ways; extensive geologic field mapping of outcropping formations coupled with geophysical work is carried out during the summer while portable mineral core rigs are used to help delineate the subsurface in outlying areas during the summer and at the mine during the winter.

The summer drilling program typically begins in early June and extends into the first two weeks of September. During this time, three to five mineral core rigs operate 24 hours a day. Core is collected in twenty-foot increments from depths of 1,500 to as much as 3,500 feet of total depth. The core is boxed and flown by helicopter to the mine site for geologic review. In all, approximately 20 to 40 exploration coreholes are drilled each summer to identify and delineate zinc deposits away from the mine site.

This practice has been extremely successful for Teck Cominco, leading to the discovery of four major zinc finds in the vicinity of the Red Dog Mine - Anarraaq, Aqqaluk, Paalaaq and Paalaaq North (Figure 2). Altogether, these zinc finds are anticipated to hold, based on probable, indicated and inferred reserves, 16.2 million tons (14.7 million tonnes) of zinc, 4.5 million tons (4.1 million tonnes) of lead and 


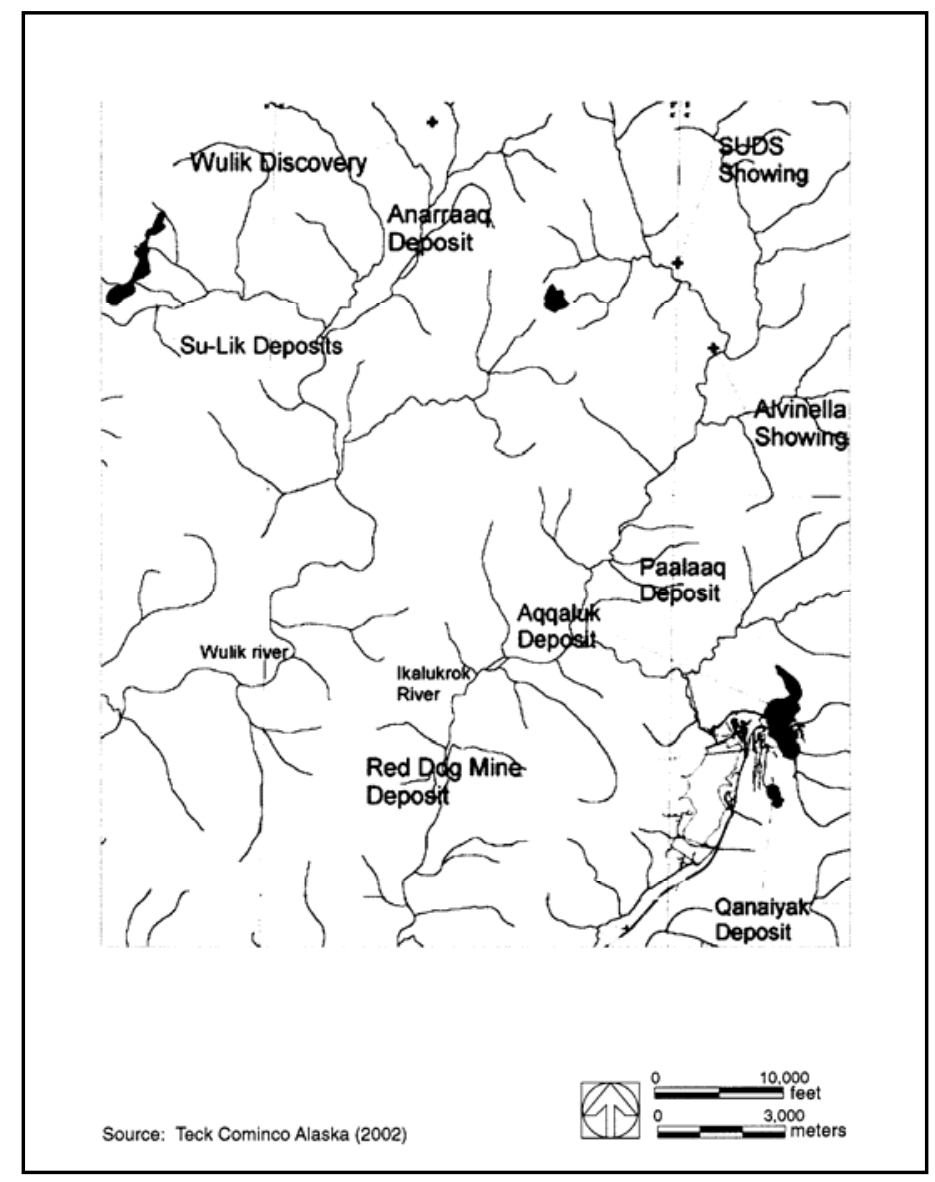

Figure 2 - Zinc deposits in the vicinity of the Red Dog Mine

4,620 tons (4,190 tonnes) of silver ${ }^{1}$. As a comparison, the proven reserves for Red Dog are approximately half of the aforementioned values for zinc, lead and silver ${ }^{1}$.

During exploratory coring for minerals, Teck Cominco has also identified the presence of natural gas occurring within thick organic shale formations within the North and Wulik Basins (Figure 3). Here and hereafter, "Basin" is used as a colloquialism and refers more appropriately to allochthons and not to the more traditional definition of the word. Shale gas was first observed in the North Basin area in 1998 and the Wulik Basin in 1999. To date, methane appears to be pervasive in areas containing little or no lead/zinc mineralization.

Although step-out exploration is only a three month effort, mining at Red Dog is a year round process requiring the manpower of hundreds of individuals, including the miners, mill operators, haul truck drivers and support staff. However, due to the remoteness of the Red Dog Mine, energy costs are extremely high as the mine uses nearly 18 million gallons of diesel oil a year to generate power for the mine complex; all of which is barged into Teck Cominco's port facility to the south and then trucked to the mine. In an effort to reduce those costs associated with mine site power generation, Teck Cominco has undertaken a multi-year exploration study to assess the feasibility of powering the mine site with methane gas contained within the organic black shales in the vicinity of the mine. 


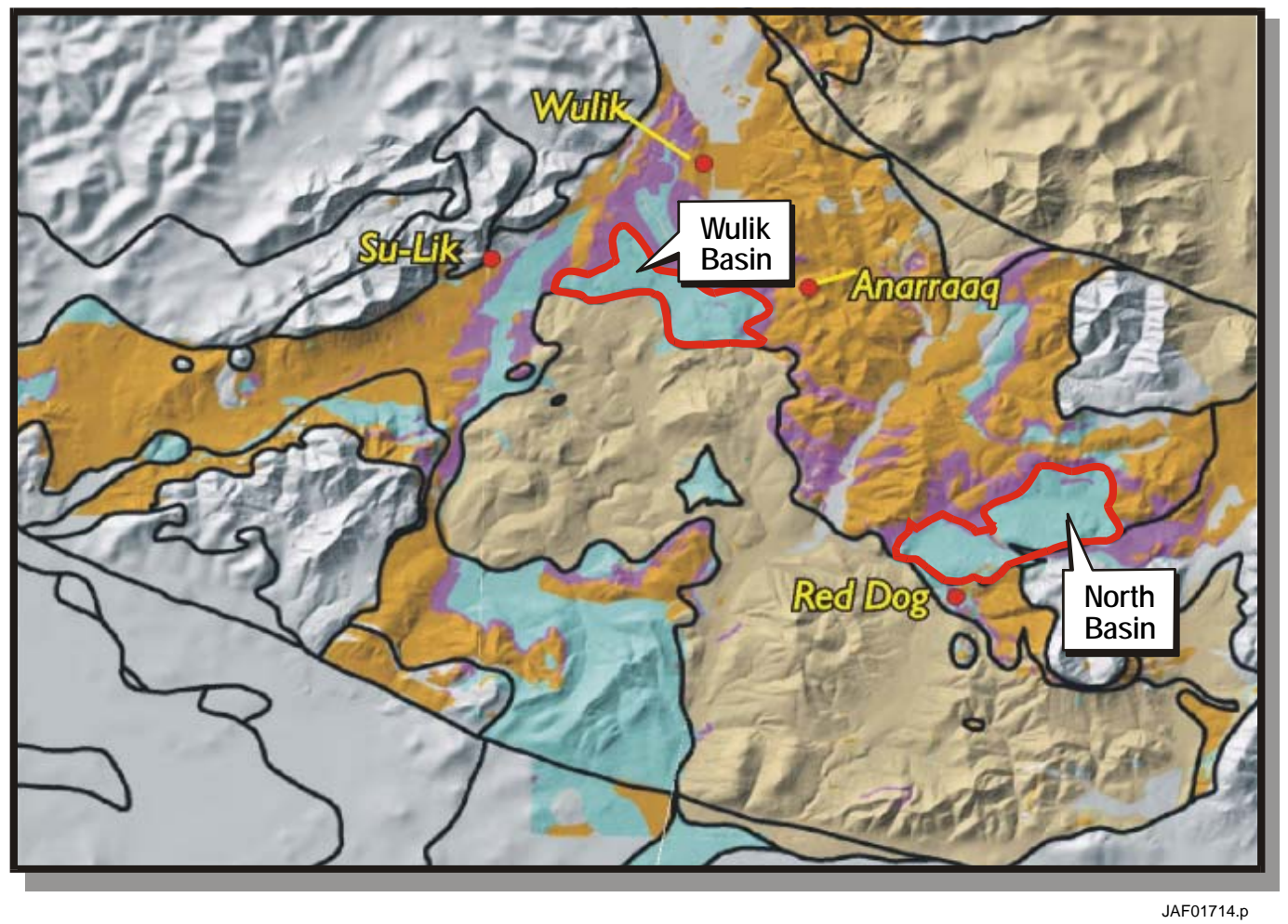

Figure 3 - Relative locations of the Wulik and North Basins to the Red Dog Mine

\section{Section I}

\section{Geology}

The western Brooks Range consists of eight major allochthons ${ }^{2}$ that were emplaced one on top of the other as a result of northward thrusting during the Cretaceous Brookian Orogeny. This movement has generated compressional stresses that have produced intense fracturing and faulting throughout the region. Of these, the Brooks Range Allochthon is the host for the Red Dog Mine's mineral and methane deposits. Major subdivisions of this allochton are the upper Key Creek plate and the mineralrich Lower Red Dog plate

The prominent stratigraphic group of the Lower Red Dog plate is the Mississippian/ Pennsylvanian age Kuna Formation (Figure 4). This unit is characterized as a highly fractured and faulted thick marine sedimentary rock consisting of a sequence of black shale, cherts, and carbonates ranging in thickness from 200 to 1,000 feet. Consistent with the nature of the highly faulted and fractured region, these older Mississippian and Pennsylvanian strata have often been thrust over the top of younger rock.

The two stratigraphic members of the Kuna Formation are the upper Ikalukrok and lower Kivalina (Figure 5). The Ikalukrok is composed of an upper black chert zone, which varies in thickness from 15 to 100 feet, and a lower black shale zone, which is about 600 to 700 feet in thickness. The Lower Kivalina Member is composed of a thin gray limestone interbedded with thin black shale. Its average thickness is about 400 feet. 


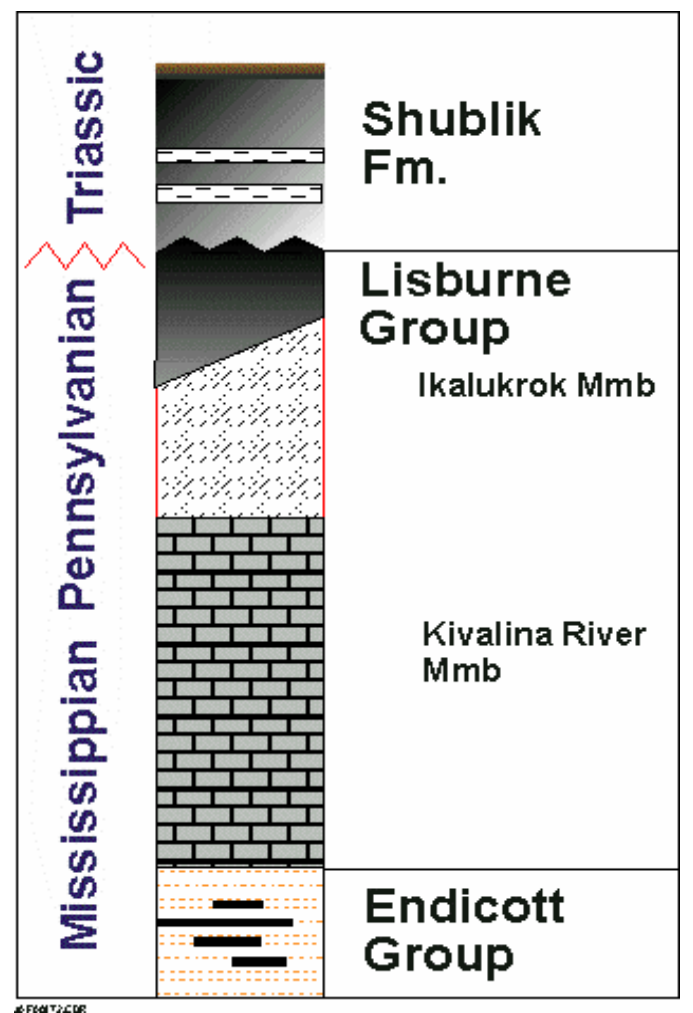

Figure 4 - Generalized stratigraphic column

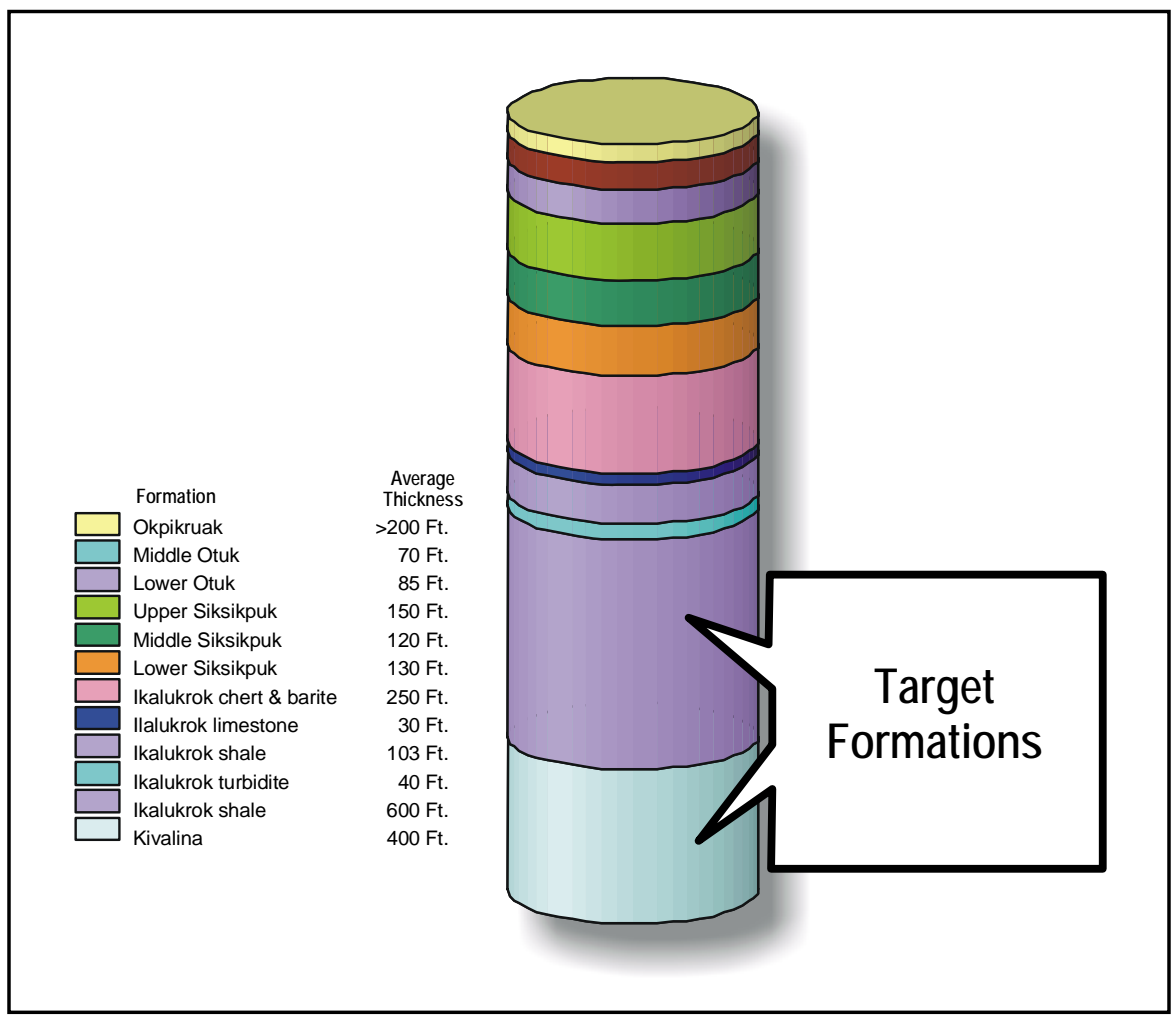

Figure 5 - Relative positions and thicknesses of the Ikalukrok and Kivalina shales 
Through gas content sampling and whole core observation, the Ikalukrok Shale and Kivalina Shale have been identified as the primary investigation targets for methane development in the region. In addition to these shale formations, the mélanges of these rocks, thick zones ( $>100$ feet) created by brittle shearing into both the foot and hanging walls of faults, have also been targeted as an exploration possibility.

The Kuna Formation has been well characterized in the area of the mine by Teck Cominco exploration core drilling and geologic analysis. In addition to routine mineral exploration drilling, a 17,000-foot exploration well (Lisburne \#1) was drilled in the area of the mine by a major oil and gas company. The stratigraphy displayed a pattern of intense structural deformation. Over the full depth of the well, the Kuna Formation was repeated five times in overthrust relationships, demonstrating the potential for thousands of feet of completable pay.

\section{Concurrent Exploration}

Initial shale-gas exploration efforts in the vicinity of the Red Dog Mine were conducted in conjunction with Teck-Cominco's mineral exploration program. From 1998 to 1999, the exploration work concerned itself with capturing representative core samples of Ikalukrok shale, Kivalina shale and their mélanges for laboratory analysis. During this time nearly 150 core samples from eleven coreholes were analyzed for gas content, total organic carbon (TOC) and gas composition. In addition one shale desorption/adsorption isotherm analysis was performed.

The results of this effort were very positive as gas content values for the organic shales were found to range from 10 to $50 \mathrm{scf} /$ ton, with half of the samples ranging from 30 to $50 \mathrm{scf} /$ ton (Figure 6). As the regression line shows, a correlative trend of increasing gas content with decreasing bulk density was found. A comparison of the bulk density and gas content results with data available from the Antrim and New Albany Shale gas plays (Figure 7) shows the Lisburne Group is very similar to that of the Antrim Shale. Further, gas composition analysis showed that the adsorbed methane was nearly $100 \%$ methane, with less than 1\% CO2 and ethane.

For the isotherm analysis, the core sample used was representative of a gas-bearing Ikalukrok shale, with a measured TOC of 6\% (Figure 8). Figure 8 depicts the adsorption isotherm passing through the collected gas content data from the corehole of interest, suggesting the shale is fully saturated with respect to gas. Again, a comparison of the collected adsorption isotherm data indicates that the Red Dog Shale is similar to the Barnett Shale of the Fort Worth Basin and the Ohio Shale of the Appalachian Basin (Figure 9).

Core sampling in Teck Cominco's summer 2000 shale-gas exploration program resulted in the collection of 58 samples gathered from 7 coreholes. Laboratory 


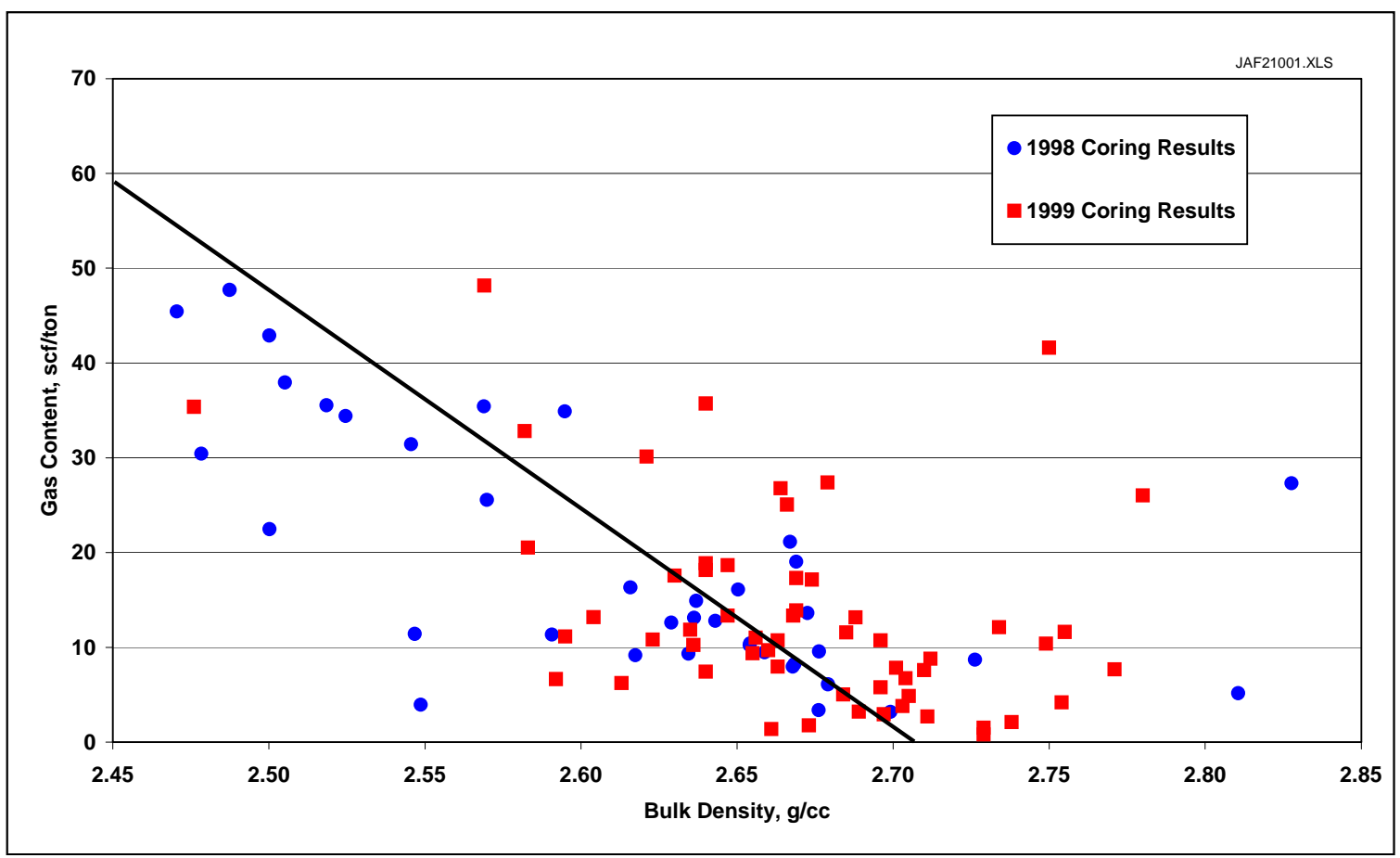

Figure 6 -1998 and 1999 gas content analysis results

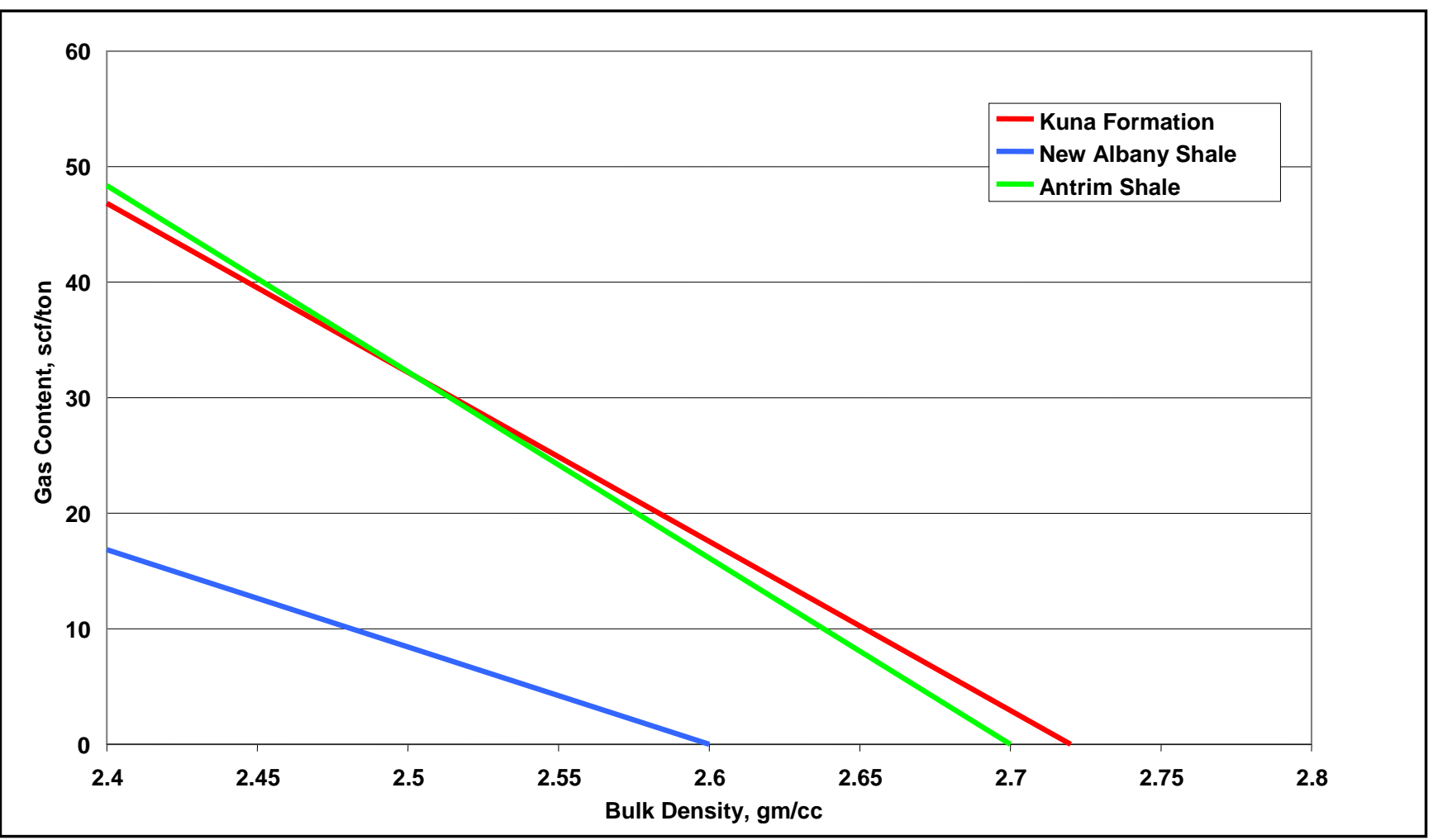

Figure 7 - Comparison of representative shale plays to the Kuna Formation 


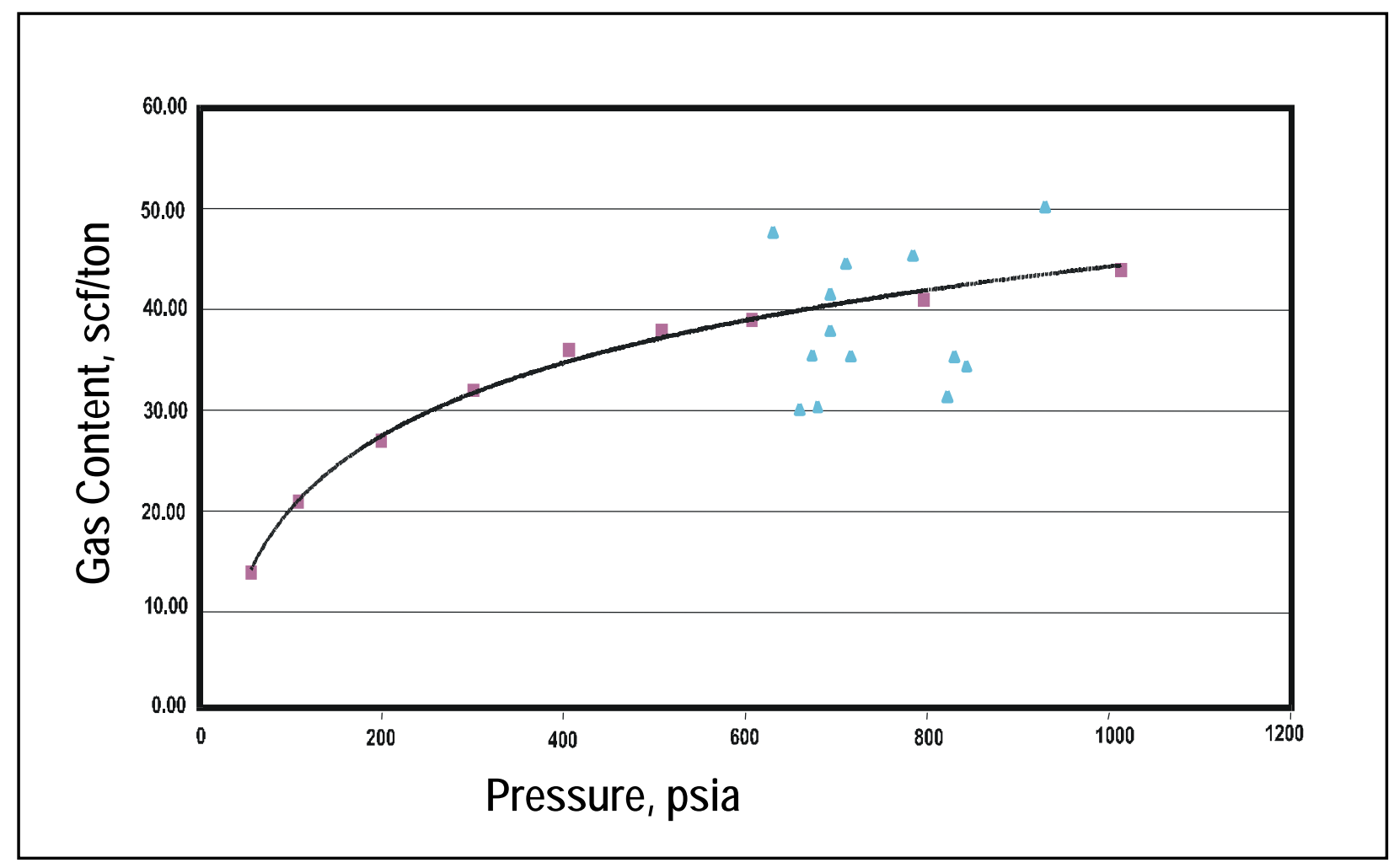

Figure 8 - Fully saturated Kuna Formation adsorption isotherm

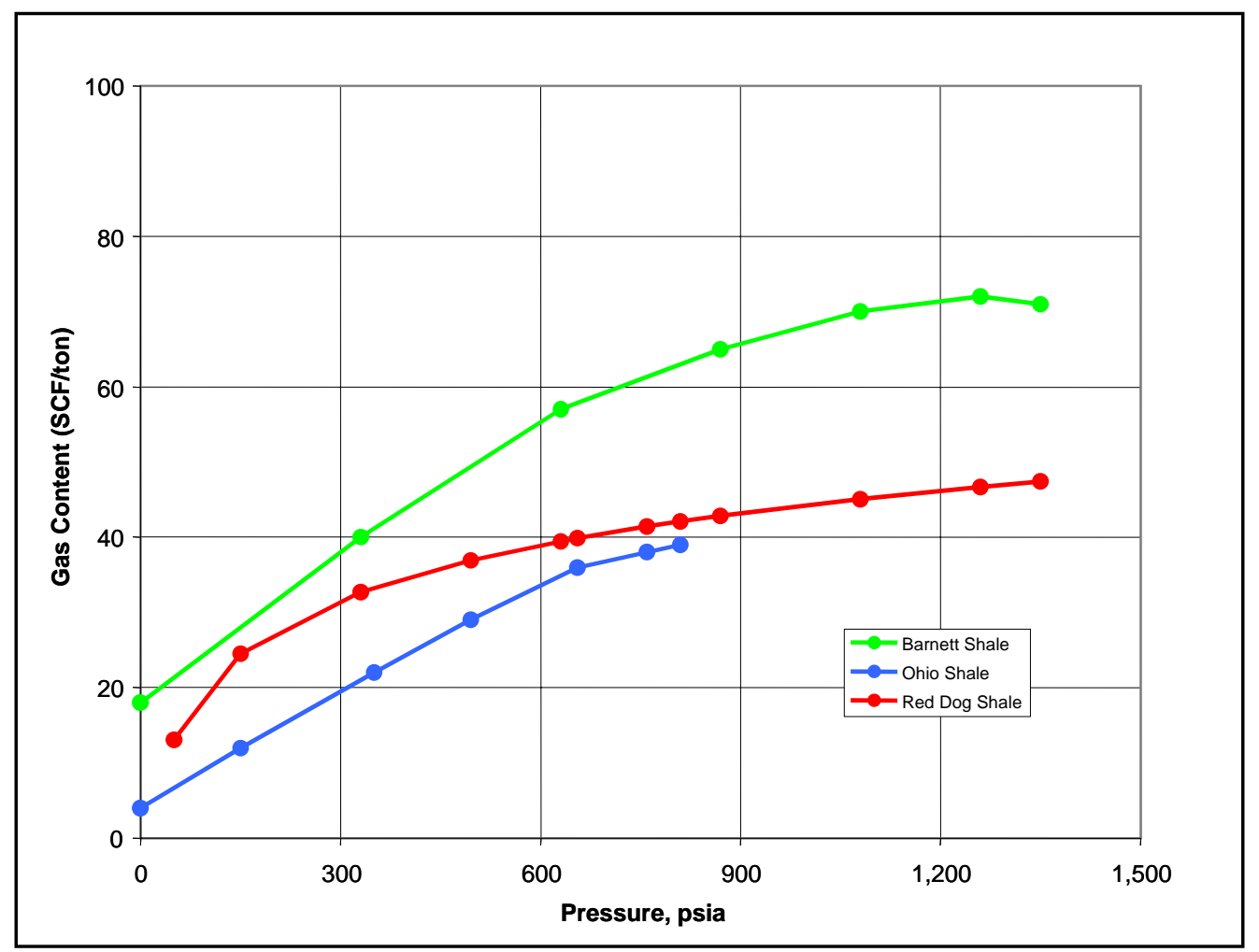

Figure 9 - Comparison of Ikalukrok shale's adsorption isotherm to other shale reservoirs 
analysis of the samples indicated that those samples with bulk density values of 2.55 g/cc or less had gas contents greater than $40 \mathrm{scf} /$ ton (Figure 10). In addition to the core sampling, Teck Cominco expanded their gas exploration to include wireline logging and pressure transient testing of representative shale strata for the purpose of determining permeability.

Since coring testing operations were to be conducted using NQ-sized coreholes (3.04 inch diameter) through as much as 600 feet of permafrost, several key operational factors were considered. These included abating the advancement of the permafrost in static holes, wireline tool for use in slimholes and pressure transient testing equipment for use in slimholes.

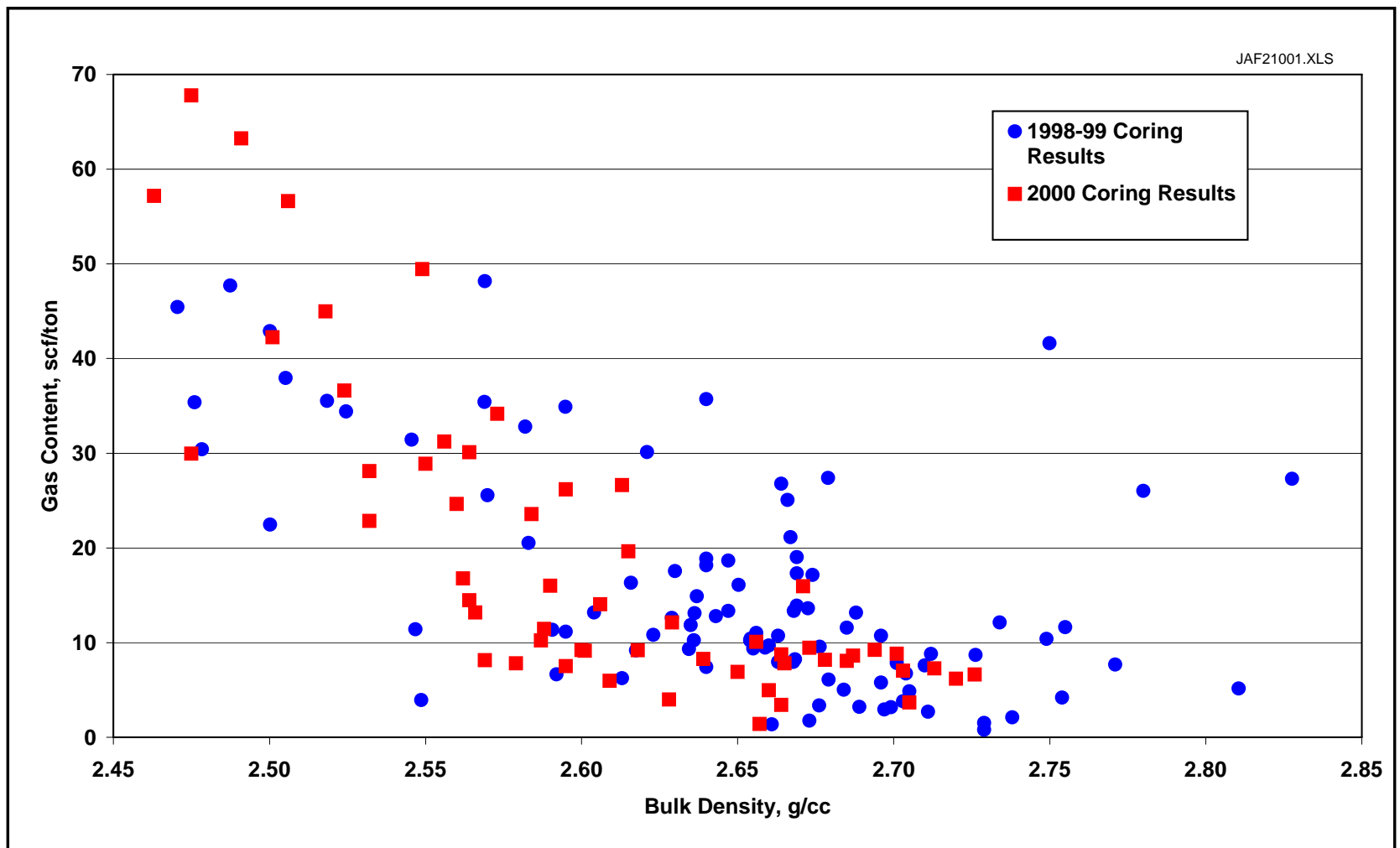

Figure 10 - 2000 Gas content analysis results

Hole Preparation - As a drilling fluid, the contractor used a liquid polymer emulsion comprised of Baroid's EZ-Mud Plus and water. When drilling was ongoing, the dynamic properties of the fluid were sufficient to maintain and even expand the thawbulb in the permafrost zone. However, it offered little or no protection from freezing under static conditions. So in order to maintain an open hole, anti-freeze mixtures (compounds) were needed.

Two prominent choices of antifreeze were ethylene glycol and propylene glycol. While ethylene glycol had superior freeze depression (Figure 11) ${ }^{\mathbf{3}}$, it also had moderate health and contact risks identified on its Material Safety Data Sheet ${ }^{4}$. On 


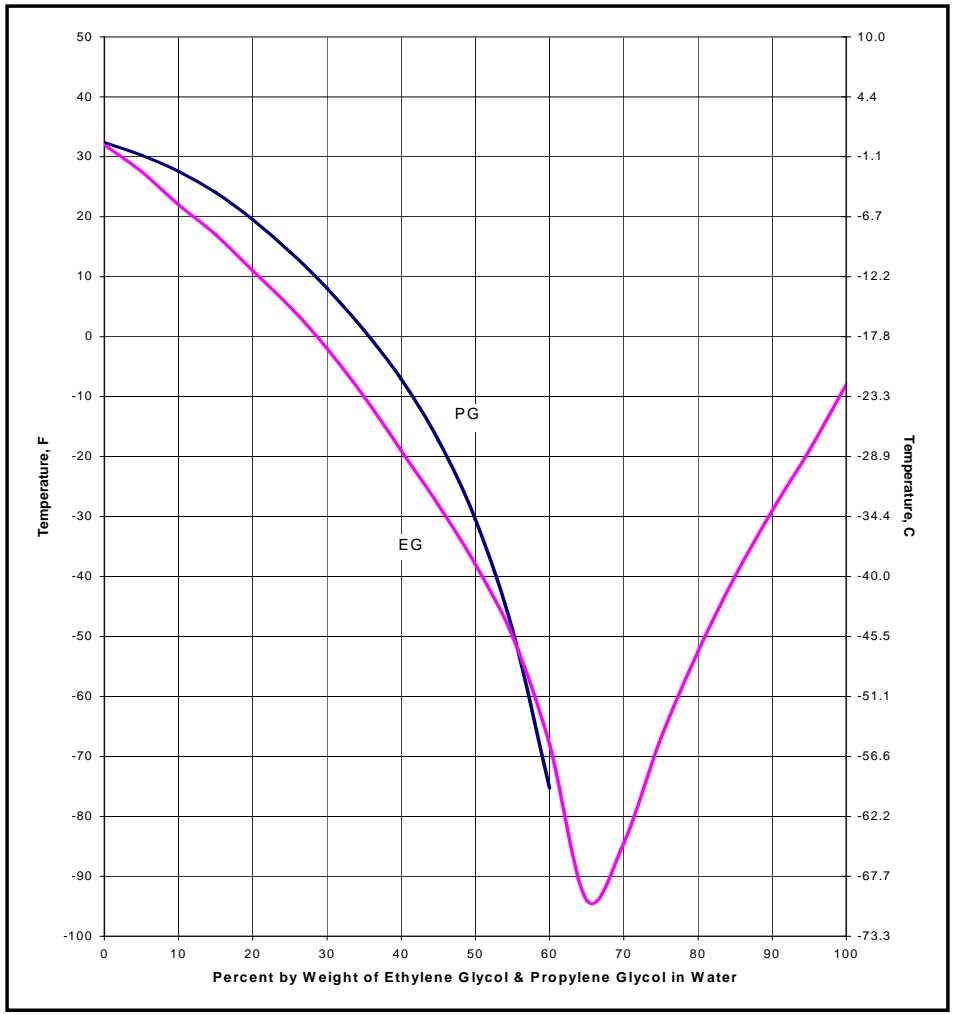

Figure 11 - Freeze depression of propylene and ethylene glycol as a function of mixing weight

the other hand, propylene glycol had no health risk and only a slight contact risk ${ }^{\mathbf{5}}$. Further, the ecological impact of each revealed that they were biodegradable if spilled to the ground. Ultimately, propylene glycol was selected for use as antifreeze.

Since the permafrost is generally found to be at temperatures of about $30^{\circ} \mathrm{F}$ in the mine area, a mixture of $15 \%$ (by weight, Figure 11) propylene glycol and water was sufficient to maintain an openhole environment under static operating conditions. Since coreholes without propylene glycol antifreeze had been known to freeze shut in as little as 12 hours, this proved to be an extremely successful program. The wellbores remained open for the 24 to 36 hours of well logging plus the 48 to 72 hours of pressure transient testing. Later, an equivalent mixture of propylene glycol and water was utilized in the injection testing fluid to prevent freezing during the pressure falloff period.

Geophysical Logging Program - The requirements were to provide a full slimhole wireline logging suite (Gamma Ray, Caliper, Resistivity, Sonic, etc.) as well as the means for conveying the downhole tools in a light, easy to transport package. Since the logging unit and tools are moved from hole to hole by helicopter, heavy equipment was not desirable. Although these necessities effectively eliminated the conventional oil and gas wireline operators due to extreme costs, three mineral logging firms were identified that could conduct the requisite logging program. They were Reeves Wireline of Pretoria, South Africa, Quantec Logging Services, Inc. of Waterdown, Ontario, and Robertson Geologging of Cypress, Texas. Ultimately, Reeves Wireline was chosen to provide the logging service. 
The four-well logging program consisted of running gamma ray/ temperature/ differential temperature/ 3-arm caliper, resistivity (FE), induction, p-wave sonic and acoustic borehole televiewer/ gamma ray logging tools (Figure 12). Each tool was run from a portable wireline winch at logging speeds of approximately 16 to 33 feet (5 to 10 meters) per minute and was oriented vertically in the hole using two spring centralizers. Unfortunately, a density tool was not run in this logging suite as approval for a radioactive source was not obtained in time. Geophysical information was collected at intervals of about 0.4 inches $(1 \mathrm{~cm})$ from total depth to surface. A typical response is shown in Figure 13.

The last logging tool run in each test well was the acoustic borehole televiewer. Information provided by the televiewer included bedding planes, fractures and other lithologic heterogeneities. The televiewer log was run over smaller sections of each corehole as logging time was considerably slower (6.5 feet or 2 meters per minute) than other tool runs. Figure 14 depicts a sample acoustic borehole televiewer response. In general, the analysis of the collected acoustic data showed good fracturing suggesting good permeability.

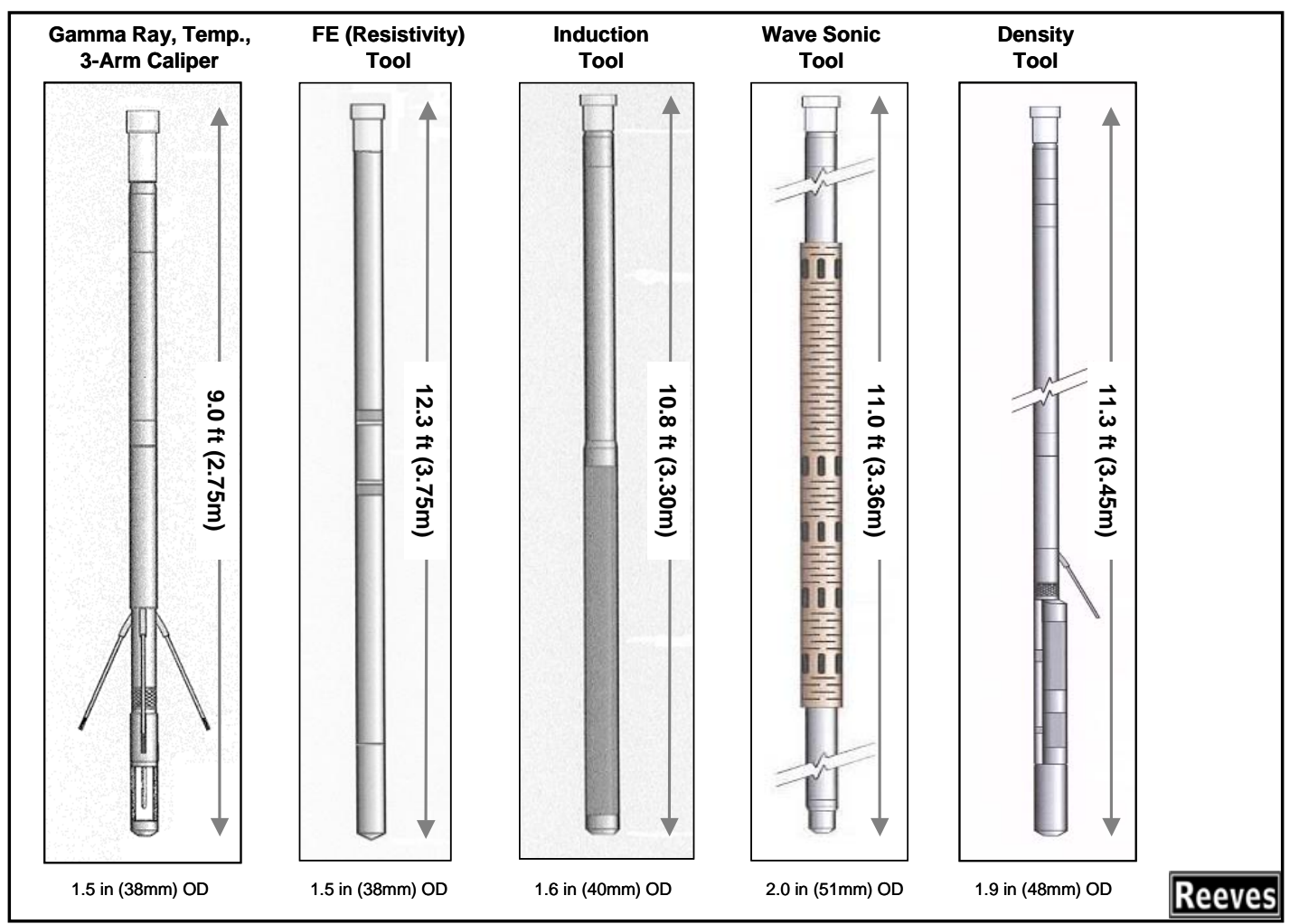

Figure 12 - Diameters and lengths of Reeves wireline logging tools

Pressure Transient Testing - Since production/buildup transient testing may lead to unwanted multi-phase (gas and water) production, water injection was chosen to maintain a single-phase (water) fluid system. Assuming no free gas resides in the system, single-phase injection testing would mitigate the negative effects of multi- 
phase relative permeability and lead to the determination of the absolute shale permeability. 


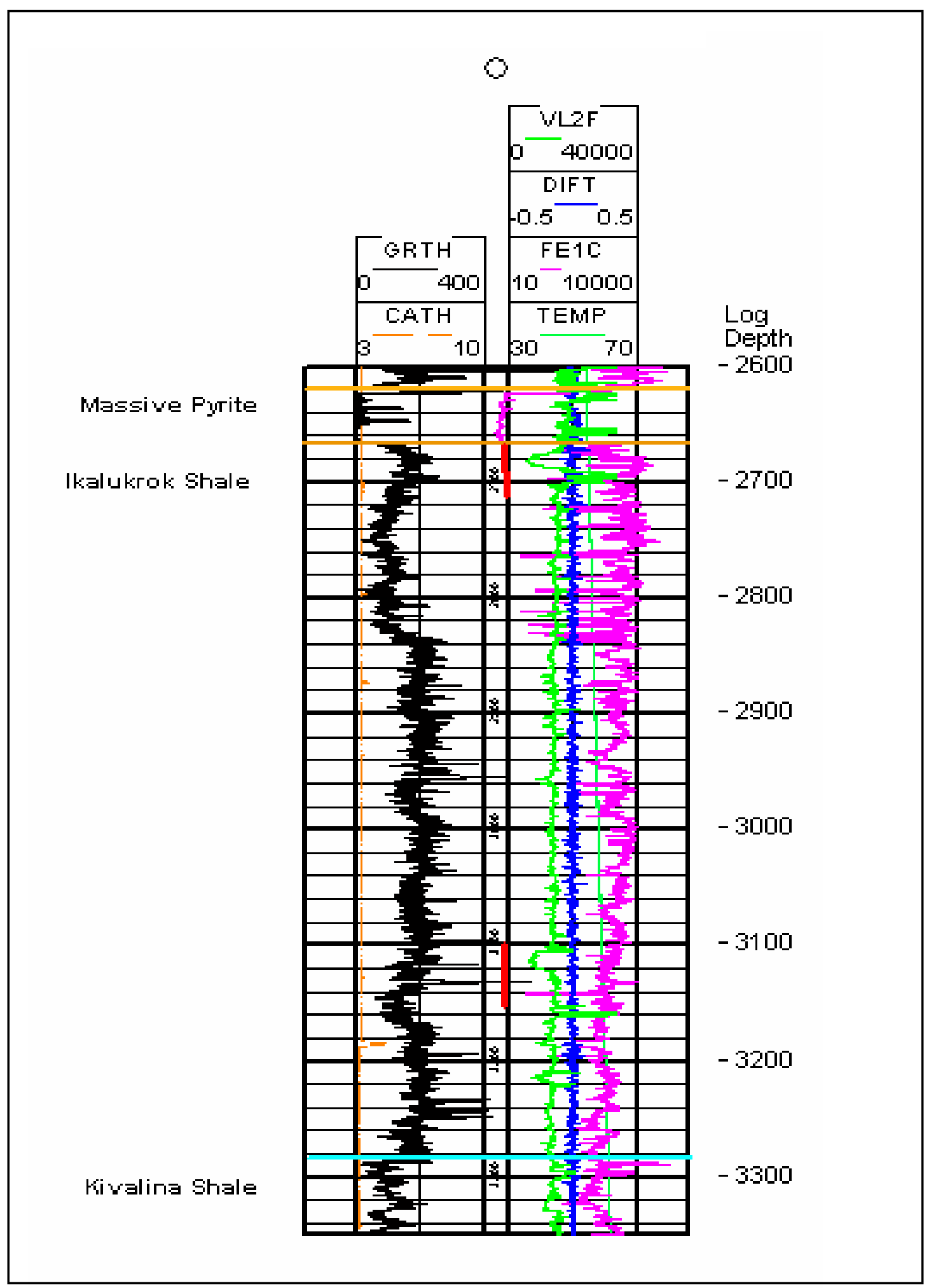

Figure 13 - Geophysical well log response 


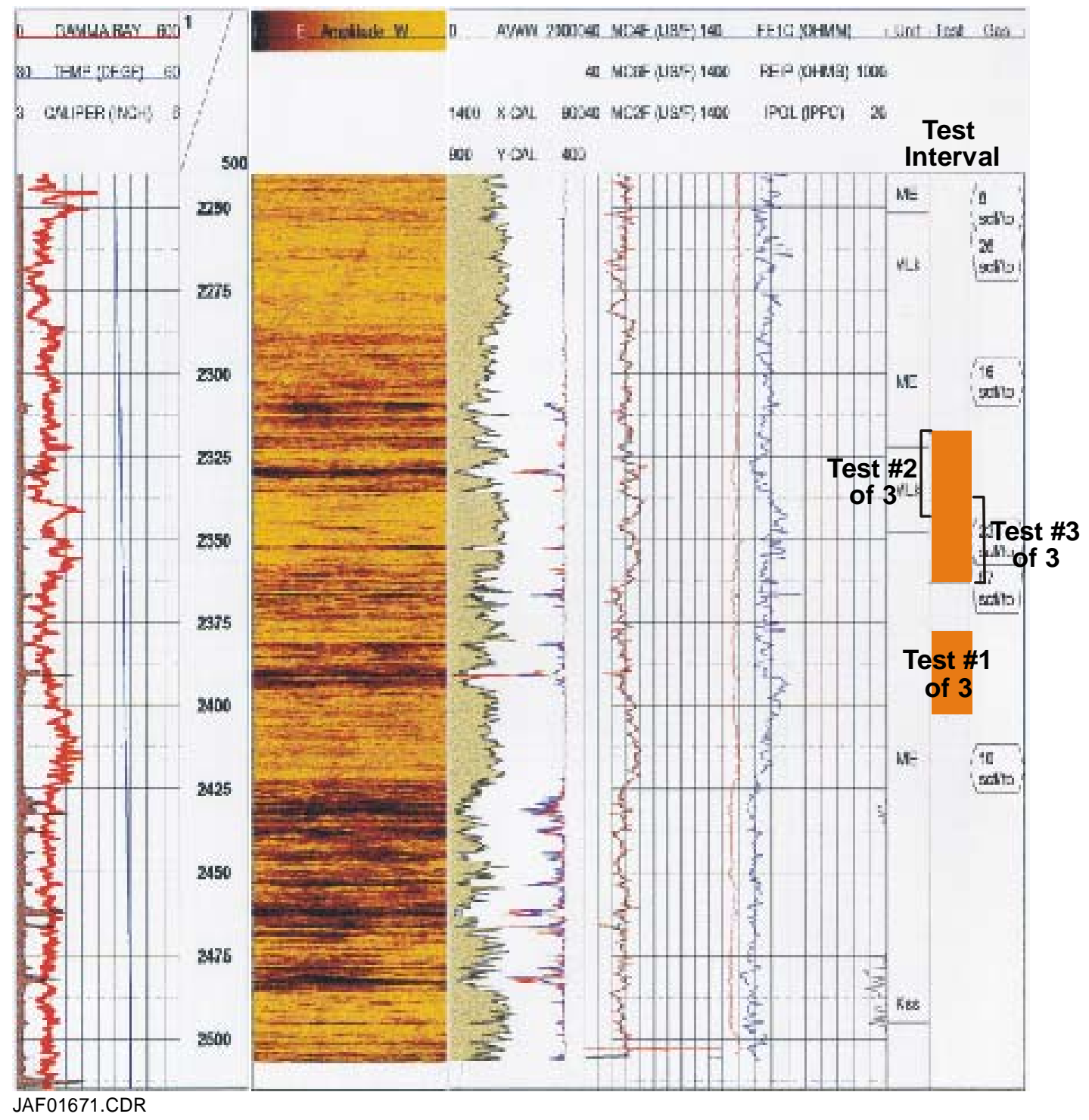

Figure 14 - Acoustic borehole televeiwer response, drillhole 945 
Specialized equipment was needed in order to conduct pressure transient tests in the NQ coreholes. In an effort to maintain a reasonable costs and rapid turnaround times, the packer equipment was sourced from a mineral equipment provider, as typical oilfield providers were considerably more expensive for similar equipment. This was further exacerbated due to the need for complete equipment redundancy.

Selected for use were Tigre Tierra's Model 23B sliding head inflatable packers with an inflatable length of 30 inches. The center tube diameter was 0.51 inches and the maximum uninflated diameter was 1.6 inches. The packers were to be used in a straddle type configuration and would each inflate to nearly 4 inches at 200 psig of unconfined pressure (Figure 15) ${ }^{\mathbf{6}}$. Packer inflation was carried out with gaseous nitrogen, conveyed to the straddle system in 3/8 inch outer diameter nylon inflation line rated to 1,000 psig. The nitrogen was stored in 255 cubic foot cylinders at a maximum pressure of 2,300 psig.

Between the straddle packers, 5/8 inch perforated and unperforated pipe as well as a downhole pressure gauge and carrier were used to make up the straddle testing section. The chosen gauge for this testing program was a Panex memory readout (MRO) gauge capable of recording more than 400,000 pressure and temperature data points at intervals as small as 0.5 seconds. The gauge was powered by six C-cell alkaline batteries, and programmed via a laptop computer. Battery testing by Panex expected a 40 hour charge at an anticipated testing temperature of $40^{\circ} \mathrm{F}$. The straddle system was conveyed to depth using the rig's 2-7/8 inch BQ drill rods.

On the surface, the drilling rig's flow manifold was used to control injection rates and their measurement. A low-pressure cumulative-type flow meter assembly (Figure 16) was constructed especially to easily tie into the manifold and to measure inflow volume and monitor surface injection pressures. The flow meter had a sensitivity of 0.1 gallons per minute and the pressure gauge could be changed to obtain the degree of accuracy desired by the tester.

Pressure Transient Testing Procedure - The methodology for selecting test intervals included core identification of the zone as Ikalukruk, Kivalina, or Shale mélange; the audible sound of methane emissions from the core sections; and the acoustic log signature of brittleness, which may indicate permeability, in the raw borehole televiewer response.

Preparation of the transient testing equipment included surface inflation testing of the packer system. Because the inflation line is fastened to the exterior of the workstring, it is exposed to the borehole face and may abrade during tripping into and out of the corehole. Also, tool retrieval may also place stress and strain on the connection joints between the packers and the inflation hose. Thus, surface inflation tests were an ideal means of ensuring integrity in the inflation system and preventing lost rig-time due to tripping, often 4 to 6 hours, to cover 2,500 to 3,000 feet of vertical depth. Inflation at the surface was carried out at an unconfined pressure of approximately 100 psi for a period of 1 hour (Figure 17). 


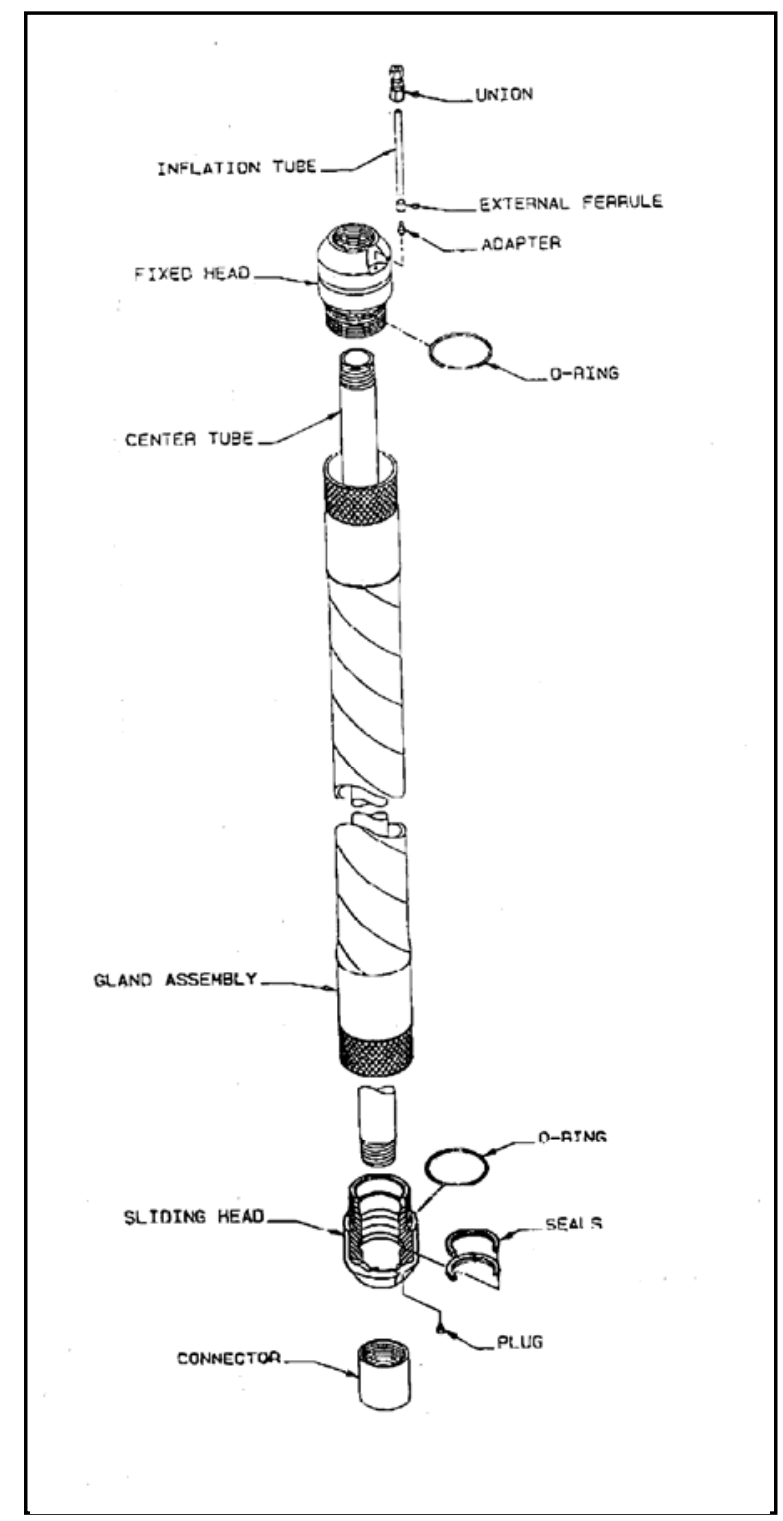

Figure 15 - Tigre Tierra Model 23 B sliding end packer (after Tigre Tierra) 


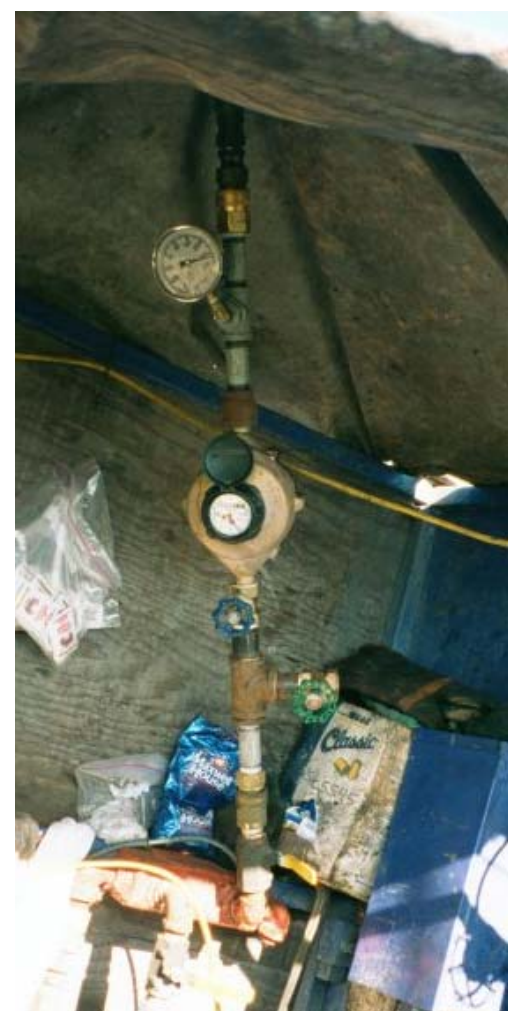

Figure 16 - Surface injection rate and pressure monitoring equipment

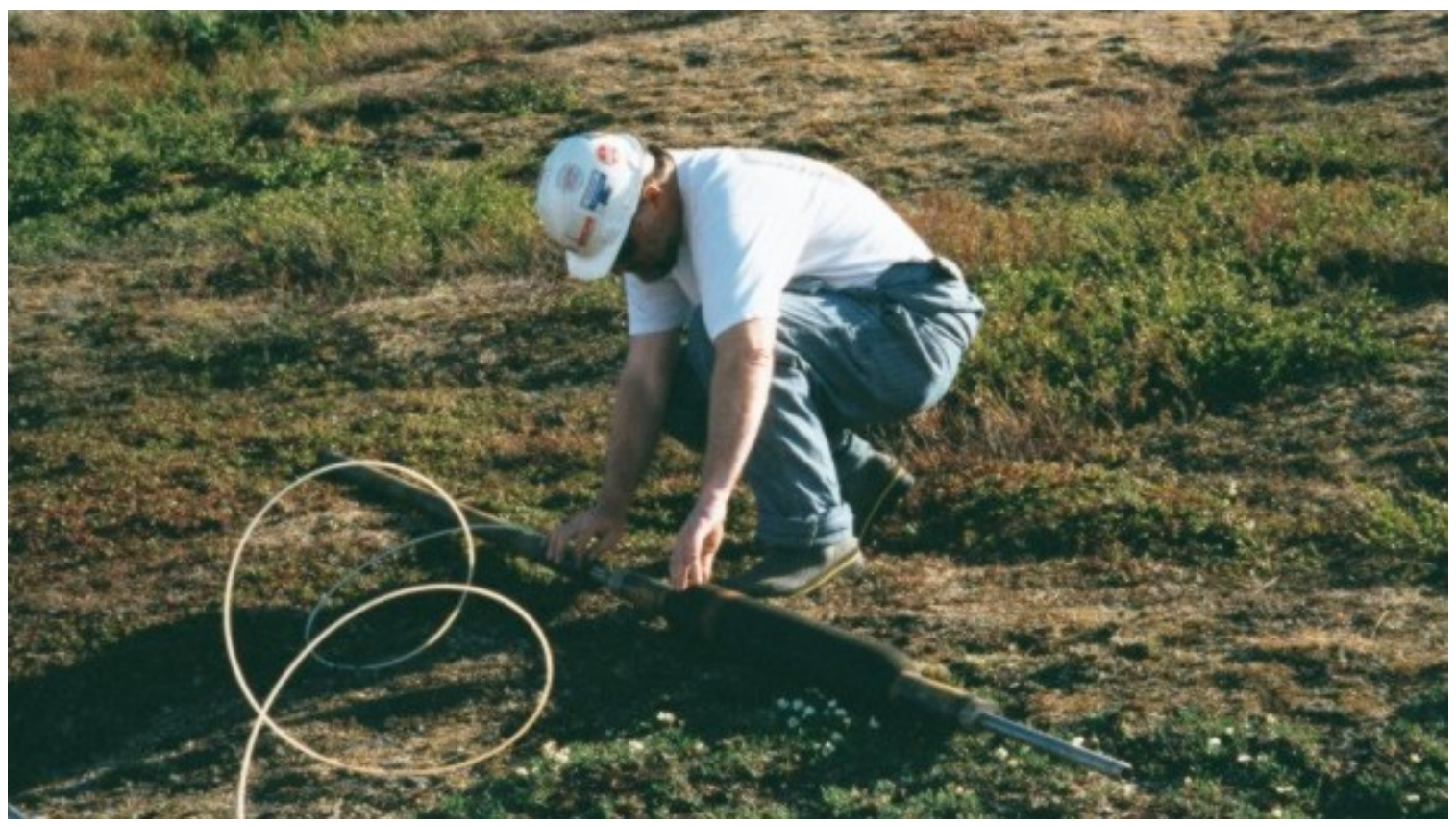

Figure 17 - Surface inflation testing 
Following inflation testing, the equipment was run in the hole. Following the insertion of the upper packer into the hole, the packer string was crossed over to BQ drilling rods for conveyance to depth. During tripping, the nylon inflation hose was attached to the drilling rods at twenty to sixty foot intervals using 1-inch electrical tape. At depth, the packers were inflated to operating pressure over a period of about 20 minutes. Pressure in the inflation system would then be allowed to equalize for the remainder of the hour before beginning the test.

Typically water injection was conducted for a period of about four hours at surface pressures less than 200 psig. After 4 hours of injection, the surface valve was closed and the pump was stopped to effectively shut-in the well for a pressure falloff period of about 8 to 12 hours. The packers were then deflated and, following a 1 hour waiting period to ensure nearly complete deflation, the equipment was retrieved and the collected pressure and temperature data was downloaded to a laptop computer.

Pressure Transient Testing Results - Table 1 shows the results from 10 transient tests conducted in four coreholes. Permeability, skin factor and reservoir pressure are reported for the specified test interval. For the five high-quality tests, the average permeability was found to be nearly $1 \mathrm{md}$ while the average reservoir pressure gradient indicated the shale reservoirs were normally pressured.

A breakout of the unsuccessful tests shows that three of the ten tests failed to provide useful permeability and skin results. Reasons for this, shown in the comments column of Table 1, include mechanical difficulties with either the packers or the inflation system. Further, a fourth test (corehole 939, August 22) yielded the highest permeability value (2.6 md) but was considered to be unreliable based on the quality of the collected pressure data. On the other hand, two of the tests conducted in corehole 936 experienced packer leaks during testing and yet valuable results were still recovered from data as the leaks were at the lower packer, albeit one was considered more representative than the other due to a more reasonable skin factor.

Table 1 - 2000 Red Dog Mine Gas Exploration Packer Test Results

\begin{tabular}{|c|c|c|c|c|c|c|c|c|}
\hline Corehole & Test Date & $\begin{array}{c}\text { Test Interval } \\
\text { feet }\end{array}$ & $\begin{array}{c}\begin{array}{c}\text { Thickness } \\
\text { feet }\end{array} \\
\end{array}$ & $\begin{array}{c}\text { Perm } \\
\text { md }\end{array}$ & Skin & $\begin{array}{c}\text { Reservoir Prs } \\
\text { psia }\end{array}$ & $\begin{array}{c}\text { Prs Gradient } \\
\text { psia/foot }\end{array}$ & Comments \\
\hline $936^{*}$ & 13-Aug-00 & $2463.75-2494.00$ & 30.25 & 0.23 & 19.5 & 901 & 0.36 & \\
\hline $936^{*}$ & 14-Aug-00 & $2494.00-2893.70$ & 400.00 & 1.10 & 3.0 & 1,070 & 0.43 & Lower Packer Leak \\
\hline 936 & 15-Aug-00 & $2403.75-2893.70$ & 489.25 & 1.72 & 162.1 & 1,072 & 0.44 & Lower Packer Leak \\
\hline 939 & 18-Aug-00 & $2503.75-2534.00$ & 30.25 & & & 1,129 & 0.45 & Upper Packer Leak \\
\hline 939 & 21-Aug-00 & $2496.75-2522.25$ & 25.50 & & & 1,043 & 0.41 & Nitrogen Leak \\
\hline 939 & 22-Aug-00 & $2497.75-2523.25$ & 25.50 & 2.57 & 17.4 & 1,200 & 0.48 & Unreliable Test \\
\hline $945^{\star}$ & 3-Sep-00 & $2377.75-2403.25$ & 25.50 & 0.51 & -1.8 & 1,100 & 0.46 & \\
\hline $945^{\star}$ & 4-Sep-00 & $2317.75-2343.25$ & 25.50 & 0.64 & -1.1 & 1,128 & 0.48 & \\
\hline $945^{\star}$ & 5-Sep-00 & $2337.75-2363.25$ & 25.50 & 0.01 & 7.9 & 1,100 & 0.47 & \\
\hline 943 & 7-Sep-00 & $2927.75-2953.25$ & 25.50 & & & & & $\begin{array}{l}\text { No test, N2 leak, } \\
\text { lost equipment }\end{array}$ \\
\hline \multicolumn{3}{|c|}{ Average High Quality Test } & & 0.94 & 5.52 & & 0.44 & \\
\hline
\end{tabular}




\section{Section II}

\section{DOE Funded Testing Program}

For the 2001 exploration program, the USDOE-NPTO project was in effect. This not only afforded the project team (Teck Cominco Alaska, NANA and ARI) the flexibility to explore additional avenues with regard to slimhole testing equipment providers, it also ensured the resulting techniques and methodologies that were employed in the field would be preserved for community appraisal by other rural arctic organizations.

So before continuing the shale exploration program in the summer of 2001, an assessment of the previous summer's efforts was required to determine practices and equipment that would be used with regard to hole preparation, wireline logging and pressure transient testing. If necessary, appropriate steps were taken to modify the equipment or methodology in order to improve the exploration results.

Coring Program - In 2001, Teck Cominco continued to collect core samples for gas content analysis. Results from 17 core samples, which were taken from 9 coreholes, showed that the gas content ranged from 1.5 to $70.1 \mathrm{scf} / \mathrm{ton}$ while the bulk density ranged from 2.48 to $2.73 \mathrm{~g} / \mathrm{cc}$. Average values were determined to be $18.4 \mathrm{scf} /$ ton and $2.61 \mathrm{~g} / \mathrm{cc}$, respectively. Figure 18 overlays the 2001 laboratory results on the data collected from 1998 to 2000.

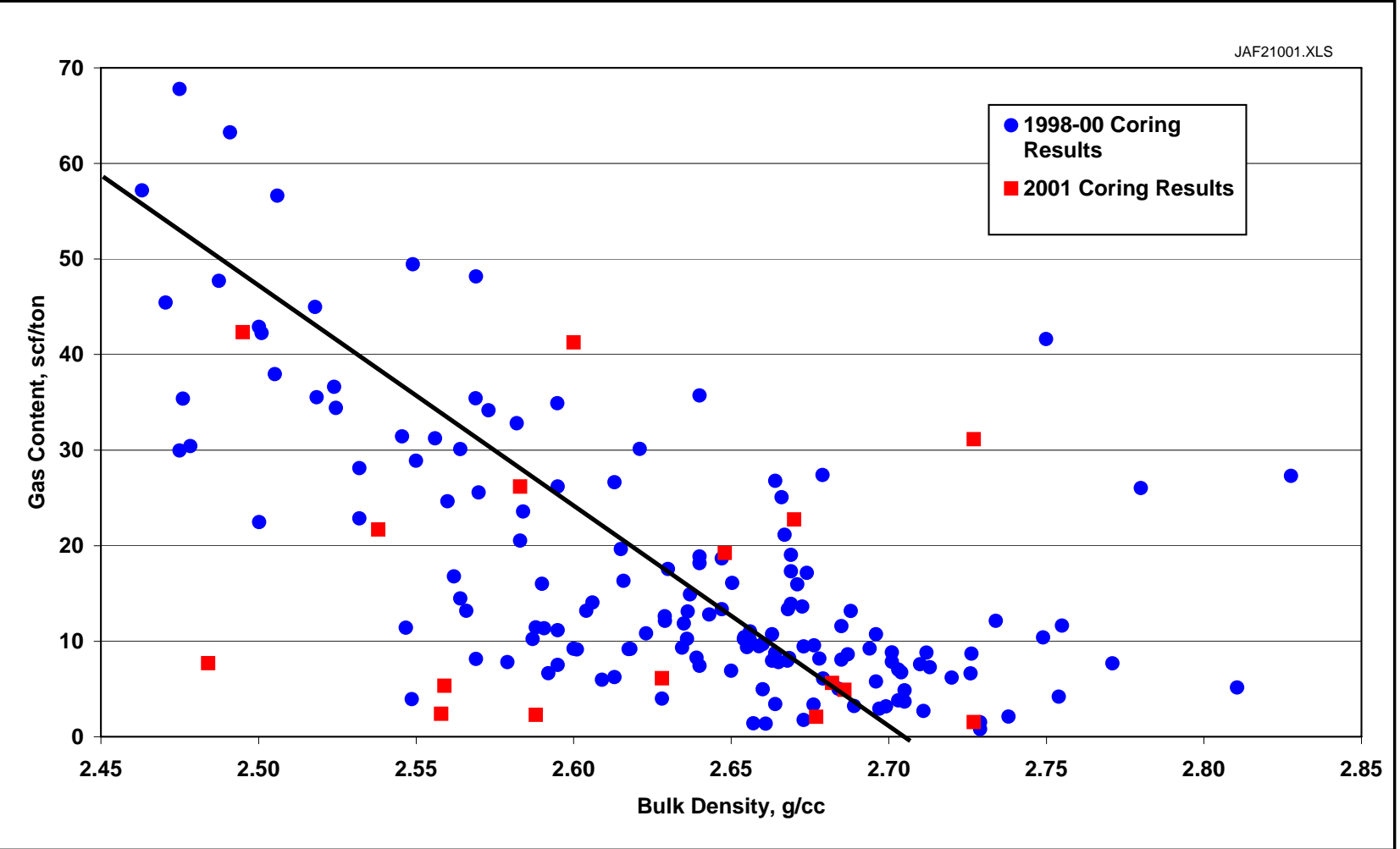


Figure 18 - 2001 Gas content analysis results

Hole Preparation - The use of propylene glycol was a very successful part of the previous year's logging and transient testing program. In fact, it was so successful that a few coreholes, under drilling conditions, required propylene glycol to counteract permafrost that was rapidly advancing into the borehole.

Geophysical Logging Program - Reeves Wireline conducted geophysical logging in the NQ-sized coreholes. The logging suite consisted of a gamma ray, differential temperature, caliper combination run and resistivity, sonic velocity, acoustic borehole televiewer and density tools. Logging was generally conducted in an openhole environment and in an 85/15 fresh water/propylene glycol fluid system. However, all density tool responses were captured inside of an NQ drill string to minimize the potential of tool loss. Log responses were also collected for the entire depth of the hole, where possible, with the exception of the acoustic televiewer tool, which was generally run over the final 1,000 feet of the well.

During logging, a sonic velocity tool was temporarily stuck in corehole \#1107. To remedy the possibility of further tool sticking/loss in the \#1107, the remaining logging tools used a string of NQ drill pipe to convey the equipment past problematic borehole areas to collect additional, logging data. Unfortunately, the acoustic televiewer tool was of a larger diameter than the internal diameter of the NQ drill rods and was not run in exploration hole \#1107.

Although the density tool's source arrived late to the Red Dog Mine, four holes \#945, \#1107, \#1109 and \#1110 were logged successfully for density response. However, logging and testing conducted at hole \#1108 was completed prior to the source arrival and the rig was released from the location.

Pressure Transient Testing Equipment - Several packer tests failed during the 2000 testing program due to packer leaks. The upper packer leaks were due to moderate injection pressures failing the rubber elements, which then inverted the packers and broke the borehole seal. This was addressed through better equipment selection during the following year's testing program. On the other hand, the lower packer leaks were not mechanical failures and were attributed to poor sealing over a fractured interval.

The final test of the 2000 program was conducted on hole 943. This corehole was essentially vertical through the first 1,500 feet of depth and deviated to a maximum of \pm 15 degrees at total depth of about 3,000 feet. Program design was for one test at a depth of 2,927 feet. Unfortunately, following 8 hours of tool tripping, the packers would not inflate and would not hold pressure, as indicated by the rapidly depleting nitrogen tanks. So, the tools were tripped out.

During tripping, the inflation line is suspected to have severed and then bypassed at least the upper packer. No line returns occurred for the final 1,500 feet of tool removal, leading to line balling in the hole and the ultimate loss of the straddle 
packers and Panex gauge as the pull weight was greater than that 5/8 inch spacer rods could bear. To address these potential failure points in upcoming programs, a more robust spacer system would be used. Further, the line would be strapped to the BQsized workstring more frequently with superior tape.

Several packer providers were requested to supply quotations for a suitably robust slimhole packer system. Those providers responding were Tam International, Weatherford Enterra, Baker Hughes and Baski, Inc. Based on price, quality and intended range of use, Baski, Inc. provided the best combination of testing equipment.

The selected packers were the MD 2.4 NIT sliding end (constant length) packers. These packers are medium duty packers normally capable of withstanding 500 psi of unconfined pressure or 1,500 psi of confined pressure. However, the packers used for testing were equipped with nitrile tubes, which provide additional reinforcement of the inflation element, for inflation with nitrogen gas, raising the packer's unconfined pressure rating to 1,500 psi. Additional packer characteristics are an uninflated diameter of 2.4 inches, a maximum suggested diameter of 4.5 inches, a mandrel pipe length of 40 inches and its internal diameter of 0.75 inches $(19 \mathrm{~mm})$.

In addition to the inflatable packers, Baski, Inc. was also able to provide heavier steel tubing for use between the inflatable packers. For this purpose, NPT-threaded $3 / 4$ inch pipe and the appropriate cross-over connections were chosen. For potentially challenging situations, like the \pm 15 degrees of hole deviation experienced during an earlier test, cross-over connections for using the BQ-sized drilling rods as spacer pipe were purchased.

Other key components purchased from this equipment provider included an access port valve and several in-line adapters. The access port valve acted as a downhole shut-in tool, which when opened allowed injection fluid to pass out of the workstring. This tool was pneumatically controlled by pressure differential, provided by the pressurized nitrogen, across it. The in-line adapters provided a means of passing the inflation line into and out of the workstring in order to bypass the packers and access port valve. Figure 19 shows the layout of the straddle packer system and the key pieces of equipment sourced from Baski, Inc.

The tool string depicted in Figure 19 consisted of, from top to bottom, a BQ cross over to $3 / 4$ inch NPT pipe, a $3 / 4$ inch NPT nipple, an in-line adapter (used to pass the inflation line into and out of the pipe body), the upper packer, a second in-line adapter, a 3/4 inch NPT nipple, an access port valve (used as a downhole shut-in tool), a $3 / 4$ inch NPT nipple, a third in-line adapter, a $3 / 4$ inch NPT blanking nipple, a $3 / 4$ inch NPT to BQ pipe cross over, 40 feet of BQ drill rods, a 52 inch perforated BQ drill rod 


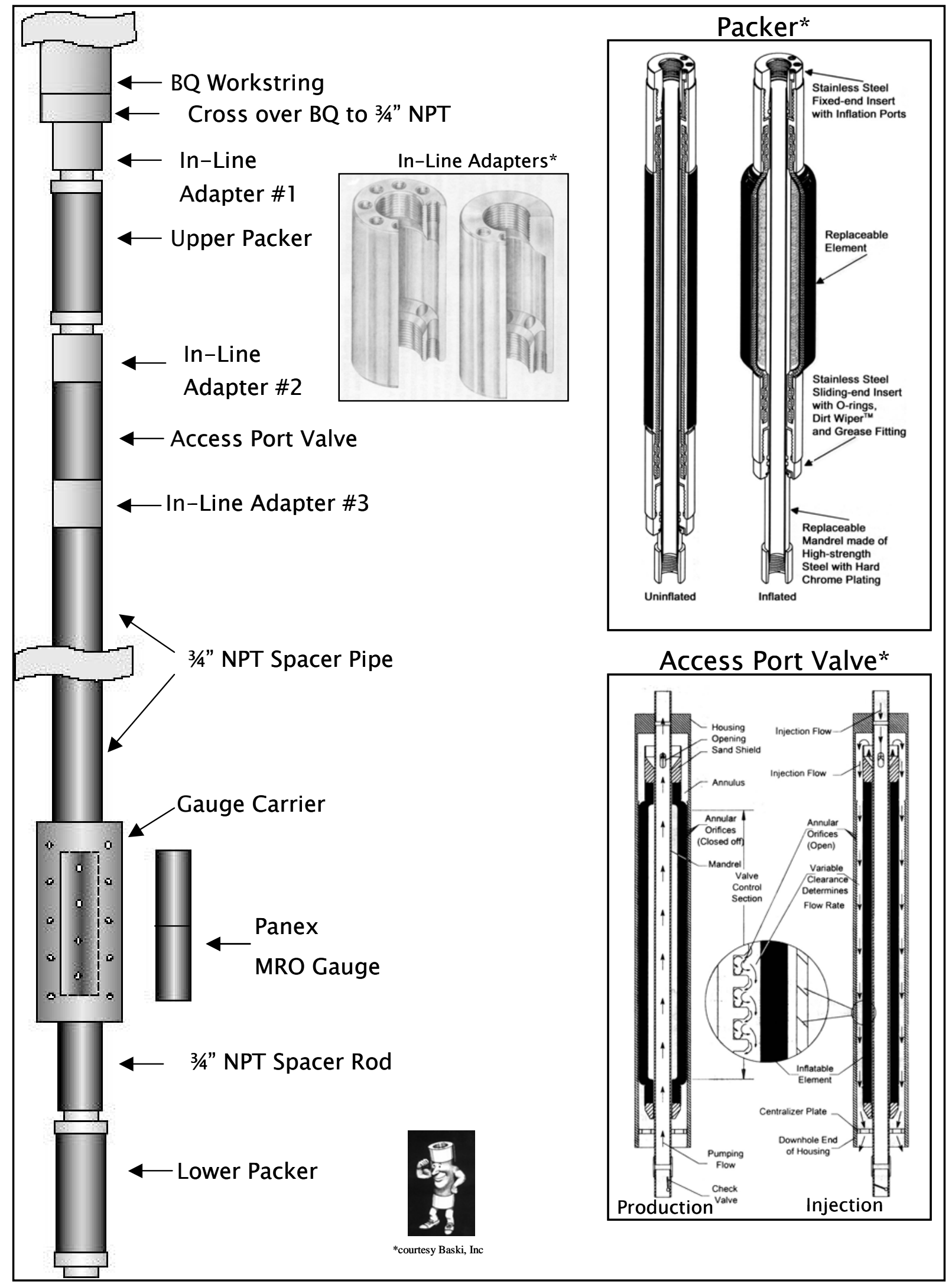

Figure 19 - Straddle packer system configuration with equipment insets 
for use as the gauge carrier, a BQ cross over to $3 / 4$ inch NPT pipe, the lower packer and the bottom $3 / 4$ inch NPT pipe plug.

Although all the inflation line used in the subs was 3/16 inch stainless steel tubing, the inflation line between the upper and lower straddle packers was $1 / 4$ inch nylon tubing. The inflation line from the upper packer to the surface was also $1 / 4$ inch nylon tubing, which was strapped to the outside of the BQ drill rod work string every ten feet using 2 inch wide by 0.01 in thick vinyl electrical tape (Scotch ${ }^{\mathrm{TM}} 22$ brand). This worked very well. In the previous year, the tape could be essentially peeled off the workstring by hand, if it was still attached, as the straddle system was retrieved. In the 2001 program, nearly every taping held and required a knife to remove the tape from the workstring.

Because the packer systems and the access port valve both required nitrogen delivery, two lines were used for transient testing. Line one inflated the upper and lower packer as well as providing a base pressure to open the access port valve. A pressure greater than that provided to line one was delivered to line two when the access port valve required closing at the end of the injection period. Figure 20 depicts the multiple inflation tank and line delivery system.

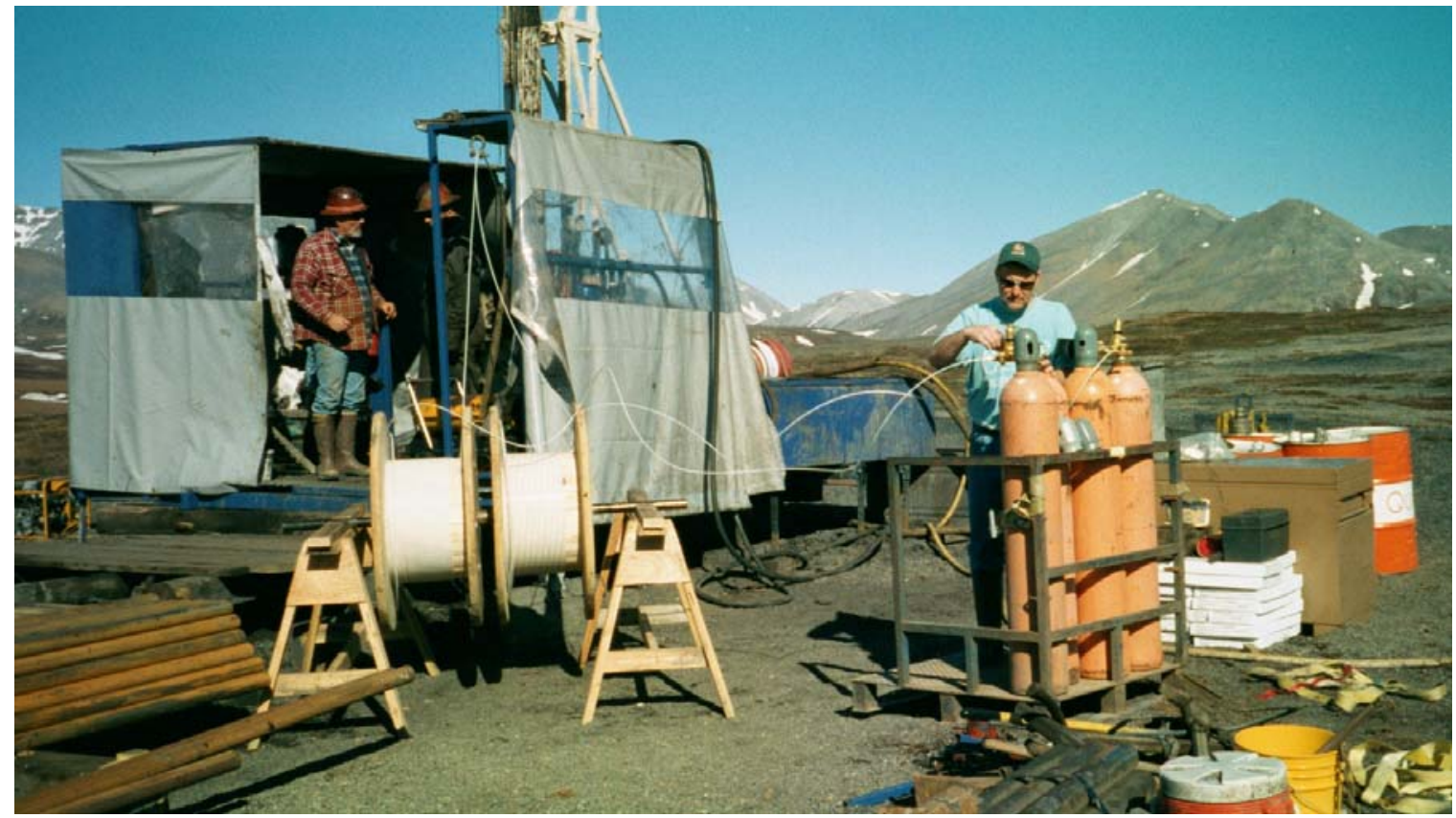

Figure 20 - Surface inflation equipment in use

Unfortunately, on it's first use the access port valve was filled with drilling sediment that bridged open the tool. This was most likely due to unnoticed solid materials in the injection tanks. Once collected bottomhole pressure data confirmed the tool was not working properly, the input for line two on the tool was closed and only one inflation line was used for the remainder of the tests. 
As with the previous year's program, equipment redundancy was the rule. Two bottomhole MRO gauges were on location at all times as well as a complete straddle packer assembly and two reel sets of stainless steel and nylon inflation line. Due to the cost of the stainless steel inflation line, it was thought that a primary set of stainless steel inflation line would be adequate and that the set of nylon line would serve as a suitable low-cost backup.

Ultimately, the nylon inflation line, due to its flexibility, proved to be easier to convey into and out of the hole as compared to the stainless steel line. Therefore, unless the hole conditions require the use of a more robust inflation system, nylon inflation line may prove the best conventional use system.

For whichever inflation line used, a means of strapping the line to the conveyance workstring is a necessity. The year 2000 testing program used 1 inch vinyl electrical tape to strap the line to the drill rods at intervals of 20 to 60 feet, which worked adequately.

Pressure Transient Testing Procedure - Recommended pressure transient test zones were based upon a combination of geophysical log response, core log lithologic description and information noted while drilling. Selection criteria from geophysical logs included strong gamma ray response ( $>150$ API), differential temperature (possible evidence of cooling in the wellbore) and caliper anomalies, elevated resistivity values and velocity slow downs. Selection criteria from lithologic core descriptions included identified mélange zones, fracture and fault zones and reported gas crackle. Data noted while drilling included reports of gas shows.

One of the more important lessons learned from the 2000 program was that the nylon inflation tubing tended to decay with repeated equipment insertion and removal. Initially, this was not expected to be much of a problem as only a limited number of tests were to be carried out. However, repeated equipment failures led to a number of re-tests in which the entire straddle packer system was removed from the hole and refit for testing. So, reducing the number of tool trips into and out of the hole would help prolong the life of the nitrogen inflation line and decrease rig execution time.

Since the bottomhole temperatures that were encountered during testing $\left( \pm 47^{\circ} \mathrm{F}\right.$ ) were higher than the $40^{\circ} \mathrm{F}$ the gauge manufacturer benchmarked battery life against, it was thought that more than 40 hours of test data could be captured. If so, there may be enough battery life to conduct multiple tests on a single tool run. In addition to prolonging tool life, implementing this methodology could effectively conserve more than 12 hours of rig time during multiple zonal tests on one tool run.

The methodology proved highly successful in its only application of the year 2000 testing program. Two consecutive straddle tests were conducted on corehole 945, saving about 15 hours of rig time in the process. Unfortunately, a rod miscount led to 
tests that were conducted 20 feet shallower than desired, requiring an additional to test to capture data from the primary zone of interest (2,337 feet).

This procedure was continued on a permanent basis under the DOE program for the 2001 pressure transient testing program. Coreholes where data was desired on multiple zones were tested on a single tool run with injection periods and pressure falloff durations of approximately 4 hours and 12 hours, respectively.

Pressure Transient Testing Results - Table 2 contains the permeability testing results from the five well program conducted in June 2001. The results for hole \#1109 are estimated as the gauge failed to record more than one hour of a nearly forty hour, two-zone, data set. Using injection rate as a proxy; however, the permeability of the deep and shallow test zones are expected to be on the order of $0.7 \mathrm{md}$ and 0.1 md, respectively. This is a reasonable assumption as the surface injection pressures were similar ( \pm 20 psig) for all tests, with a consistent straddle interval.

Table 2 - 2001 Red Dog Mine Gas Exploration Packer Test Results

\begin{tabular}{|c|c|c|c|c|c|c|c|c|}
\hline Corehole & Test Date & $\begin{array}{c}\begin{array}{c}\text { Test Interval } \\
\text { feet }\end{array} \\
\end{array}$ & $\begin{array}{c}\text { Thickness } \\
\text { feet }\end{array}$ & $\begin{array}{l}\text { Perm } \\
\text { md }\end{array}$ & Skin & $\begin{array}{c}\text { Reservoir Prs } \\
\text { psia }\end{array}$ & $\begin{array}{l}\text { Prs Gradient } \\
\text { psia/foot }\end{array}$ & Comments \\
\hline $1108^{*}$ & 9-Jun-01 & $2,880.0-2,931.6$ & 51.6 & 0.06 & (1.3) & $1,267.0$ & 0.43 & \\
\hline $1108^{*}$ & 10-Jun-01 & $2,705.0-2,756.6$ & 51.6 & 0.02 & (1.6) & $1,232.0$ & 0.45 & \\
\hline 1107 & 11-Jun-01 & $2,696.0-2,747.6$ & 51.6 & 0.03 & $n / a$ & $1,216.0$ & 0.44 & Iow quality \\
\hline $1107^{*}$ & 12-Jun-01 & $2,560.0-2,611.6$ & 51.6 & 8.50 & $(5.0)$ & $1,144.0$ & 0.44 & \\
\hline 1107 & 12-Jun-01 & $1,477.0-1,528.6$ & 51.6 & 0.01 & $n / a$ & 650.0 & 0.43 & low quality \\
\hline $1110^{*}$ & 19-Jun-01 & $1,700.0-1,751.6$ & 51.6 & 0.16 & (2.6) & 786.3 & 0.45 & \\
\hline 1110 & 20-Jun-01 & $1,240.0-1,291.6$ & 51.6 & 0.09 & $n / a$ & 546.0 & 0.42 & low quality \\
\hline $945^{*}$ & 22-Jun-01 & $2,220.0-2,271.6$ & 51.6 & 0.01 & (1.2) & $1,017.8$ & 0.45 & \\
\hline $1109^{*}$ & 24-Jun-01 & $3,101.5-3,153.1$ & 51.6 & 0.70 & & & & gauge failure \\
\hline $1109^{*}$ & 25-Jun-01 & $2,661.5-2,713.1$ & 51.6 & 0.07 & & & & gauge failure \\
\hline \multicolumn{3}{|c|}{ gh Quality Test } & & 1.36 & (2.34) & & 0.44 & \\
\hline
\end{tabular}

*High Quality Test

It is also worth noting that in drill holes 945 and 1110, the drillers used bentonite as a fluid loss additive during drilling. Since the radius of investigation for each hole was very small during transient testing, this has most likely manifested itself as a reduction to the measured permeability values for those tests, indicating true permeability may be larger as only the permeability of the damaged zone was measured.

For the five high-quality tests and two 1109 tests, the average permeability was found to be $1.4 \mathrm{md}$ while the average reservoir pressure gradient indicated the shale reservoirs were normally pressured. These values are influenced greatly, however, by the large permeability response seen on hole 1107 . Without this value, the average permeability drops to $0.2 \mathrm{md}$. 
Calculated permeability data generated from the tests were compared with their corresponding geophysical well log and lithologic core description (Table 3). The tested zones were then sorted by calculated permeability value. Two data clusters emerged including a greater than $0.1 \mathrm{md}$ (high) cluster and a less than $0.1 \mathrm{md}$ (low) cluster.

\section{Table 3 - Ranked pressure transient tests with core and log characteristics}

\begin{tabular}{|c|c|c|c|c|c|c|c|c|c|c|c|}
\hline & \multirow[b]{2}{*}{ Ranl } & \multirow{2}{*}{$\begin{array}{c}\text { Core } \\
\text { Hole \# }\end{array}$} & \multirow{2}{*}{$\begin{array}{l}\text { Test } \\
\text { Year }\end{array}$} & \multirow{2}{*}{\begin{tabular}{|l|} 
Tested \\
Interval \\
\end{tabular}} & \multirow{2}{*}{\begin{tabular}{|l|} 
Core Log \\
Lithologic Description
\end{tabular}} & \multicolumn{2}{|c|}{ Reported Gamma } & \multirow{2}{*}{\begin{tabular}{|c|} 
Diff \\
Temp
\end{tabular}} & \multicolumn{2}{|c|}{ Resistivity Velocity } & \multirow{2}{*}{$\begin{array}{c}\text { Caliper } \\
\text { anomaly }\end{array}$} \\
\hline & & & & & & Perm & Ray & & & & \\
\hline & 1 & 1107 & 2001 & $2560-2611$ & Kivalina sh, interbedded Is, calcite lined faulting, open space & 8.5 & $50-100$ & yes-strong & $250^{*}$ & $4600 \mathrm{~m} / \mathrm{s}$ & yes \\
\hline & 2 & 1109 & 2001 & 3102-3153 & Ikalukrok w/faulting and fracture, gouge fault, calcite veining & 0.7 & $200-250$ & no & 1500 & $3600 \mathrm{~m} / \mathrm{s}$ & yes \\
\hline & 3 & 945 & 2000 & $2318-62$ & Kivalina shale- minor turbidite \& melange of Kivalina \& Opikruak & 0.64 & $75-100$ & no & 400 & $4600 \mathrm{~m} / \mathrm{s}$ & yes \\
\hline & 4 & 945 & 2000 & $2378-2403$ & melange of Kivalina \& Okpikruak & 0.51 & $75-125$ & no & 700 & $4600 \mathrm{~m} / \mathrm{s}$ & yes \\
\hline high & 5 & 936 & 2000 & 2463-94 & melange of Ikalukrok with minor fault at base & 0.23 & $100-200$ & no & 500 & $5200 \mathrm{~m} / \mathrm{s}$ & yes \\
\hline rank & 6 & $1110^{*}$ & 2001 & $1700-52$ & melange of Okpikruak w/gouge fault & 0.16 & $50-125$ & yes-strong & 600 & $4800 \mathrm{~m} / \mathrm{s}$ & yes \\
\hline perm & 7 & $1110^{*}$ & 2001 & 1240-1292 & Kivalina gray shale with minor fault at base & 0.09 & $75-100$ & yes-strong & 500 & $4200 \mathrm{~m} / \mathrm{s}$ & no \\
\hline low & 8 & 1109 & 2001 & $2662-2713$ & Ikalukrok shale & 0.07 & $150-200$ & yes-small & 10000 & $2600 \mathrm{~s} / \mathrm{m}$ & no \\
\hline rank & 9 & 1108 & 2001 & $2880-2932$ & melange of Ikalukrok just above thrust. & 0.06 & $150-200$ & yes-small & 800 & $4000 \mathrm{~m} / \mathrm{s}$ & yes \\
\hline \multirow[t]{8}{*}{ perm } & 10 & 1107 & 2001 & $2696-2748$ & melange of Kivalina & 0.03 & $100-250$ & yes & 1000 & $4900 \mathrm{~m} / \mathrm{s}$ & yes \\
\hline & 11 & 1108 & 2001 & $2705-2757$ & Ikalukrok shale (riding on thrust) & 0.02 & $150-250$ & no & 800 & $4200 \mathrm{~m} / \mathrm{s}$ & yes \\
\hline & 12 & $945^{*}$ & 2001 & $2220-72$ & melange of kivalina w/faulting \& shearing & 0.02 & 100 & no & 600 & $4900 \mathrm{~m} / \mathrm{s}$ & no \\
\hline & 13 & 1107 & 2001 & $1477-1529$ & melange of Kivalina & 0.01 & $50-100$ & yes-strong & 250 & $5200 \mathrm{~m} / \mathrm{s}$ & yes \\
\hline & 14 & 945 & 2000 & $2338-52$ & melange of Kivalina \& Okpikruak & 0.01 & $100-200$ & no & 1000 & $4300 \mathrm{~m} / \mathrm{s}$ & yes \\
\hline & & & & & $1110^{\star}$ Bentonite used in hole during drilling which suppresses perm. & & & & & & \\
\hline & & & & & $945^{\star}$ Bentonite used to treat hole which surppresses perm. & & & & & & \\
\hline & & & & & Data from tested intervals with packer failures not included & & & & & & \\
\hline
\end{tabular}

Relative to low permeability test zones, the high permeability zones tended to exhibit lower gamma responses (100 api vs. 200 api), a strong temperature anomaly (when recorded), and a lithologic description that usually included faults and fractures. Temperature (except strong temperature anomalies) and caliper anomalies were spread just about equally between high and low permeability. The representative values recorded for resistivity and sonic showed very little difference between high and low permeability clusters. Core samples with an audible gas crackle were most often associated with low permeability zones.

\section{Cost Comparison of Slimhole to Conventional Oilfield Exploration}

From a technical standpoint, the slimhole exploration program was quite successful. To date, more than 200 core samples have been analyzed for gas content and bulk density. In addition, two adsorption isotherms have been collected as well as 9 sets of geophysical logs. Further, 20 pressure transient tests have yielded information concerning permeability, damage factor and pressure of Ikalukrok, Kivalina and shale mélange strata. However, to extrapolate the financial success of the Red Dog Mine 
program as compared to one conducted using conventional oilfield exploration strategies is extremely difficult due to the uncertainties associated with planning, logistics and execution of such a program.

Because zinc exploration at the mine site was already a fully integrated process using multiple diamond drill core rigs, the acquisition of one to three of these coring rigs for use in gas exploration was easily accommodated for the two to three week time frame that was needed to core and test a single borehole. When the gas program was finished, the drilling rig was returned to the zinc exploration program for use until the end of the drilling season, often in early September. At this time, the rig would be broken-down and stored at the mine until the following year.

Therefore, rig mobilization charges, which often account for a considerable expense, would be minimized due to the lack of transportation to and from the Red Dog Mine by barge or other means. Further, the use of two or more core rigs greatly increased the flexibility of the program and helped reduce personnel standby costs. The use of two or more rigs, considering the site transportation and day rate cost components, may not be a luxury that other rural infrastructures can support.

So, to accomplish a fair comparison, it is best to create an exploration program template and contrast the expected costs. A fully integrated program conducted in rural Alaska, with coring, gas content sampling, geophysical logging and transient testing, would most likely span the three months of June, July and August, in order to take advantage of more favorable weather conditions. As a result of this 90 day time constraint, the drilling and testing of four to five coreholes might be a reasonable expectation for a single rig program at a location with suitable support infrastructure.

In order to build the exploration models, a set of assumptions was made. Four test holes were to be cored/drilled to a total depth of 3,000 feet. Coring times would be analogous to those experienced at the Red Dog Mine, approximately 12 days, while conventional drilling would be completed in about 7 or 8 days. However, to obtain core samples for gas content sampling, the oilfield rig would be required to core five 20 foot sections, which would then be under reamed to allow deeper drilling. Coring would add 2 or 3 days to the program for a total of 10 days.

Although drilling/coring time, would vary, it is assumed that the timing for conducting geophysical logging and pressure transient testing would not vary significantly between the two programs. Per hole, four days would be needed with 1.5 days allotted for logging and 2.5 days for testing. Therefore, the only difference in cost would be attributed to the selection of the service provider.

In a program such as this, it is recommended that the service providers (logging and testing) be mobilized and demobilized for each test hole as personnel standby costs can become quite significant. This methodology has been accounted for in the service cost estimates. However, equipment standby charges are still in effect for the idle logging and pressure transient testing gear. Fortunately, the slimhole program 
estimates account for outright purchasing of most of the necessary pressure transient testing equipment. Thus, the equipment accrues no standby costs and is usable at no future cost for other programs.

Rig and personnel movement for each scenario can be quite different. Assuming a summer program, roads would have to be built across the tundra in order to move the rig from location to location. In some cases, it is possible that road construction on the tundra would not be permitted for any number of reasons (environmentally sensitive area, for one). In these cases, longer, more roundabout roads would be required, increasing the project cost. Once completed, the roads would be reclaimed at the end of the project. Personnel would then be able to take advantage of the roads for shift changes. The slimhole program, however, requires helicopter support to enable core rig movement and personnel changes.

Each four hole program is anticipated to last approximately 65 to 70 days, with the conventional oilfield program finishing just ahead of the slimhole program. Table 4 displays the estimated cost comparison of the slimhole and conventional oilfield exploration programs, respectively. Although the slimhole program is estimated to be on the order of two-and-a-half times cheaper than the conventional oilfield program, several factors could alter this perception.

Table 4 - Cost comparison of slimhole and conventional oilfield 4-well exploration programs

\begin{tabular}{|c|c|c|c|c|c|c|c|c|c|c|c|c|}
\hline \multirow[b]{2}{*}{ Item } & \multicolumn{6}{|c|}{ Slimhole Program } & \multicolumn{6}{|c|}{ Conventional Oilfield Program } \\
\hline & Quantity & Unit & & Per Unit & & Total & Quantity & Unit & & Per Unit & & Total \\
\hline $\begin{array}{l}\text { Permitting/Rig Mobilization } \\
\text { Rig and Personnel Movement (on site)/Road } \\
\text { Drilling/Coring } \\
\text { Core Description/Sampling (1-man) } \\
\text { Laboratory Analysis } \\
\text { Geophysical Logging (2-men and Equipment) } \\
\text { Transient Testing (2-men and Equipment) }\end{array}$ & $\begin{array}{r}1 \\
4 \\
4 \\
64 \\
20 \\
4 \\
4\end{array}$ & \begin{tabular}{l|l}
1 & Rig \\
4 & Holes \\
4 & Holes \\
4 & Days \\
& Samples \\
4 & Holes \\
4 & Holes
\end{tabular} & $\begin{array}{l}\$ \\
\$ \\
\$ \\
\$ \\
\$ \\
\$ \\
\$\end{array}$ & $\begin{array}{r}50,000 \\
45,000 \\
200,000 \\
650 \\
200 \\
20,000 \\
30,000\end{array}$ & $\begin{array}{l}\$ \\
\$ \\
\$ \\
\$ \\
\$ \\
\$ \\
\$\end{array}$ & $\begin{array}{r}50,000 \\
180,000 \\
800,000 \\
41,600 \\
4,000 \\
80,000 \\
120,000\end{array}$ & $\begin{array}{r}1 \\
1 \\
4 \\
40 \\
20 \\
4 \\
4\end{array}$ & \begin{tabular}{|l} 
Rig \\
Mile \\
Holes \\
Days \\
Samples \\
Holes \\
Holes
\end{tabular} & $\begin{array}{l}\$ \\
\$ \\
\$ \\
\$ \\
\$ \\
\$ \\
\$\end{array}$ & $\begin{array}{r}340,000 \\
500,000 \\
300,000 \\
650 \\
200 \\
160,000 \\
55,600\end{array}$ & $\begin{array}{l}\$ \\
\$ \\
\$ \\
\$ \\
\$ \\
\$ \\
\$\end{array}$ & $\begin{array}{r}340,000 \\
500,000 \\
1,200,000 \\
26,000 \\
4,000 \\
640,000 \\
222,400\end{array}$ \\
\hline
\end{tabular}

First, where firm costs were unavailable for the conventional oilfield program, a 1996 study on rural Alaskan gas development was used to fill in the gaps ${ }^{7}$. These costs may be conservative by today's standards regarding big hole development.

Second, these cost estimates were determined using the basic assumption that exploration delineation would be conducted at a location that had suitable support infrastructure and was reasonably near a transportation system. The more remote an application, the larger the logistical costs in mobilizing equipment, especially a largescale drilling rig, will be. This results in a larger cost disparity between the slim and conventional holes, bringing the cost difference closer to three or four to one. 


\section{Conclusions}

o The slimhole exploration program was a technical success. More than 200 gas content analyses, eight geophysical logging runs and 20 pressure transient tests were conducted over the four-year effort.

o Based on the subsurface information gathered during zinc exploration, lithologic core sampling and laboratory analysis, geophysical logging and pressure transient testing, the Ikalukrok, Kivalina and mélanges of these formations are a viable unconventional gas resources with an estimated $>2$ TCF of gas in place.

o A similar exploration program carried out using conventional oilfield programs and practices may have been 2.5 to 5 times the cost of the slimhole exploration program, saving millions of dollars for Teck Cominco Alaska, Inc, while yielding similar results.

o Valuable information can be obtained at relatively low cost using "opportunistic" approaches to exploration. These may include core sampling and laboratory analysis, geophysical logging and pressure transient testing in mineral exploration holes.

o To maintain an open borehole through the permafrost zone, propylene glycol mixed at $15 \%$ by weight with water was extremely effective. This preventive measure lasted in some cases for periods of more than 4 days.

o Geophysical logging firms that provide services to the mining industry may have tools suitable for use in oil and gas exploration at reduced rental and usage fees, with minimal drop off in log quality.

o Low-cost inflatable packers sourced from mineral equipment providers may be suitable for use in pressure transient testing. However, extreme care must be used at all times to ensure packer integrity and avoid packer mechanical failure. In applications such as those experienced at the Red Dog Mine, it is recommended to use a strengthened medium duty packer for openhole testing to further reduce the risk of packer failure. These packers still offer considerable cost savings over the more robust traditional oilfield packers.

o Surface inflation testing of the packer string prior to running in the hole is an effective way of discovering nitrogen line leaks and loose connections. With oneway trip times of as much as six hours at the Red Dog Mine site, the potential for mitigating tens of hours of equipment trip times and rig standby costs due to inflation line failure is well worth the hour of surface testing time. An additional benefit to the procedure is the use of the inflation test to educate the rig crew on the proper use and handling of the straddle packer system and inflation line. 
o Four hours of water injection and twelve hours of pressure falloff appear to be sufficient to identify shale permeability. As many as three of these tests conducted one after the other can be accomplished on a single tool run in the hole without the fear of battery failure due to cooling effects of the permafrost.

o To prevent the injection fluid from freezing in the workstring during the pressure falloff period, the operator may want to consider the use of propylene glycol as an anti-freeze in the injection fluid.

o In transient testing programs conducted in a small number of test holes $(<6)$, nylon inflation line can be used effectively, especially when multiple zones are tested on single straddle packer test runs. While not as robust as the stainless steel inflation line, the nylon line is considerably easier to work with. However, care must be taken to strap the line to the workstring at intervals of about 20 feet using an appropriate material, such as the 2-inch wide vinyl electrical tape used in the 2001 program.

o Although equipment cost can be doubled at the project's onset, equipment redundancy is a time and cost saving scheme (from the standpoint of rig and personnel standby rates) should equipment become lost or damaged.

\section{Acknowledgements}

The authors would like to thank Teck Cominco Alaska, Inc. for the use of their Red Dog Mine facilities during the execution of this gas exploration and field demonstration project; NANA Development Corporation for project oversight and coordination between the USDOE-NPTO, Native corporations and the project team; field service providers Dynatec USA and Reeves Wireline for their contributions to this report as well as their field work; and finally, The United States Department of Energy - National Petroleum Technology Office for identifying this program as a project of worth.

\section{References}

1. http://www.teckcominco.com

2. Moore, D.W., Young, L.E., Modene, J.S., and Plahuta, J.T., 1986, Geologic setting and genesis of the Red Dog zinc-lead-silver deposit, western Brooks Range, Alaska: Economic Geology, v. 81, p. 1696-1727.

3. http://www.penray.com/bulletins/pgvseg.htm

4. http://www.jtbaker.com/msds/p6928.htm

5. http://www.jtbaker.com/msds/e5125.htm

6. Tigre Tierra Inflatable Packers Operating \& Parts Manual, Revised November 1996.

7. Foster, M., et al., Rural Alaska Natural Gas Study, a Profile of Potential Natural Gas Energy Substitution in Rural Alaska, 1996. 


\section{Appendix A \\ Multiple Zone Pressure Transient Testing Program Utilized at Red Dog Mine}




\section{Multiple Zone Pressure Transient Testing Program Utilized at Red Dog Mine}

\begin{tabular}{|l|c|}
\hline \multicolumn{1}{|c|}{ Standard Item } & Duration \\
\hline Lay out tools & 0.5 hours \\
\hline Surface inflation test and program MRO gauge & 1 hour \\
\hline Run in hole (start with deepest zone) & 3 to 6 hours \\
\hline Inflate Packers & 1 hour \\
\hline Injection test & 4 to 6 hours \\
\hline Shut-in for pressure falloff & 8 to 12 hours \\
\hline Deflate packers & 1 hour \\
\hline Pull up to next interval & 0.5 hours \\
\hline Inflate Packers & 1 hour \\
\hline Injection test & 4 to 6 hours \\
\hline Shut-in for pressure falloff & 8 to 12 hours \\
\hline Deflate packers & 1 hour \\
\hline Pull out of hole & 3 to 5 hours \\
\hline
\end{tabular}

